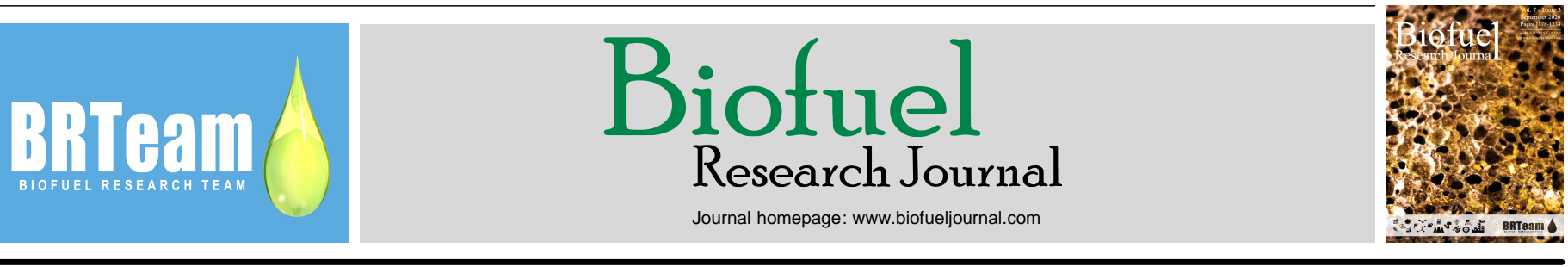

Original Research Paper

\title{
Production of sorghum pellets for electricity generation in Indonesia: A life cycle assessment
}

Edi Iswanto Wiloso ${ }^{1,2, *}$, Arief Ameir Rahman Setiawan ${ }^{1}$, Hafiizh Prasetia ${ }^{3}$, Muryanto ${ }^{3}$, Adisa Ramadhan Wiloso ${ }^{2}$, Subyakto $^{4}$, I. Made Sudiana ${ }^{5}$, Reni Lestari ${ }^{6}$, Satya Nugroho ${ }^{7}$, Dede Hermawan ${ }^{8}$, Kai Fang ${ }^{9,10}$, Reinout Heijungs ${ }^{11,12}$

${ }^{1}$ Research Center for Science, Technology and Innovation Policy and Management, Indonesian Institute of Sciences, Jakarta 12710, Indonesia.

${ }^{2}$ Pamulang University, South Tangerang 15435, Indonesia.

${ }^{3}$ Research Center for Chemistry, Indonesian Institute of Sciences, South Tangerang 15343, Indonesia.

${ }^{4}$ Research Center for Biomaterials, ${ }^{5}$ Research Center for Biology, ${ }^{6}$ Research Center for Plant Conservation and Botanic Gardens, ${ }^{7}$ Research Center for Biotechnology, Indonesian Institute of Sciences, Bogor 16911, Indonesia.

${ }^{8}$ Bogor Agricultural University, Bogor 16680, Indonesia.

${ }^{9}$ School of Public Affairs, Zhejiang University, Hangzhou 310058, China.

${ }^{10}$ Center of Social Welfare and Governance, Zhejiang University, Hangzhou 310058, China.

${ }^{11}$ School of Business and Economics, Vrije Universiteit Amsterdam, 1081 HV Amsterdam, The Netherlands.

${ }^{12}$ Institute of Environmental Sciences, Leiden University, 2300 RA Leiden, The Netherlands.

\section{HIGHLIGHTS}

$>$ Utilization of marginal land to produce sorghum pellet electricity is modeled.

$>$ Energy content of 1.12 tons of sorghum pellets is equivalent to 1 ton of coal.

$>$ Burden shifting is avoided by considering a comprehensive system boundary.

$>$ The pellet processing stage contributes the most to global warming impacts.

$>$ A sensitivity analysis shows greenhouse gas

savings ranging between $70 \%$ and $85 \%$.

\section{GRAPHICAL ABSTRACT}

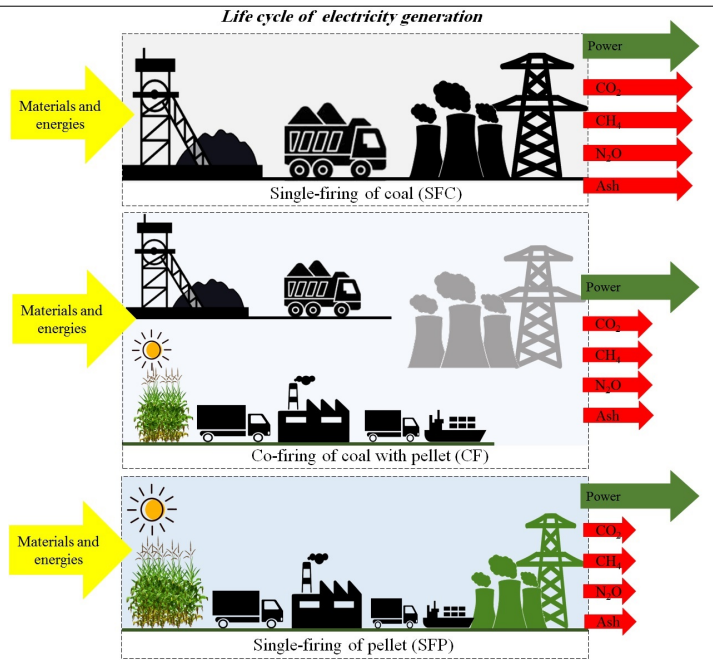

\begin{abstract}
The current study makes use of life cycle assessment to evaluate the potential greenhouse gas (GHG) savings in coal electricity generation by $5 \%$ co-firing with sorghum pellets. The research models the utilization of 100 thousand hectares of under-utilized marginal land in Flores (Indonesia) for biomass sorghum cultivation. Based on equivalent energy content, 1.12 tons of pellets can substitute one ton of coal. The calculated fossil energy ratio of the pellets was 5.8, indicating that the production of pellets for fuel is energetically feasible. Based on a biomass yield of $48 \mathrm{ton} / \mathrm{ha} \cdot \mathrm{yr}, 4.8$ million tons of pellets can be produced annually. In comparison with a coal system, the combustion of only pellets to generate $8,300 \mathrm{GWh}$ of electricity can reduce global warming impacts by 7.9 million tons of $\mathrm{CO}_{2}$-eq, which is equivalent to an $85 \%$ reduction in GHG emissions. However, these results changed when reduced biomass yield of 24 ton/ha $\mathrm{yr}$, biomass loss, field emissions, and incomplete combustion were considered in the model. A sensitivity analysis of the above factors showed that the potential GHG savings could decrease from the initially projected $85 \%$ to as low as $70 \%$. Overall, the production of sorghum pellets in Flores and their utilization for electricity generation can significantly reduce the reliance on fossil fuels and contribute to climate change mitigation. Some limitations to these conclusions were also discussed herein. The results of this scenario study can assist the Indonesian government in exploring the potential utilization of marginal land for bioenergy development, both in Indonesia and beyond.
\end{abstract}

(C) 2020 BRTeam. All rights reserved.

* Corresponding authors at:

E-mail address: ediiswanto@yahoo.com ; edi.iswanto.wiloso@lipi.go.id

Please cite this article as: Wiloso E.I., Setiawan A.A.R., Prasetia H., Muryanto, Wiloso A.R., Subyakto, Sudiana I.M., Lestari R., Nugroho S., Hermawan D., Fang K., Heijungs R. Production of sorghum pellets for electricity generation in Indonesia: A life cycle assessment. Biofuel Research Journal 27 (2020) 11781194. DOI: $10.18331 / B R J 2020.7 .3 .2$ 


\section{Contents}

1. Introduction.

1.1. The potential and importance of developing bioenergy in Indonesia

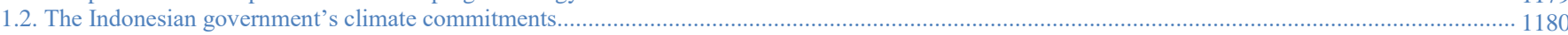

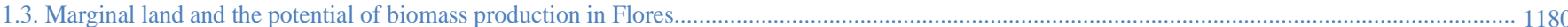

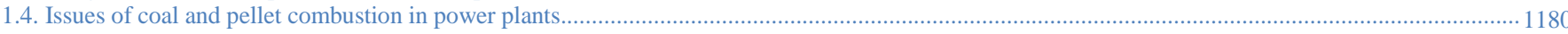

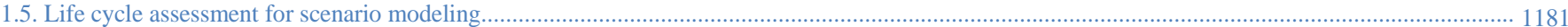

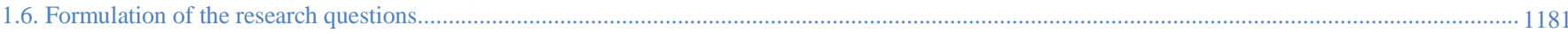

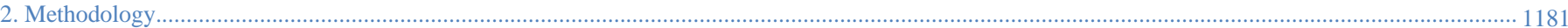

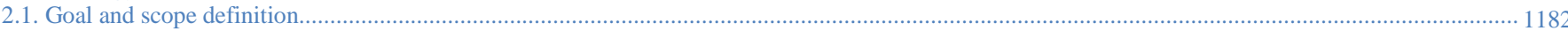

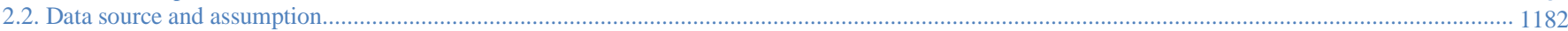

2.2.1. Data source

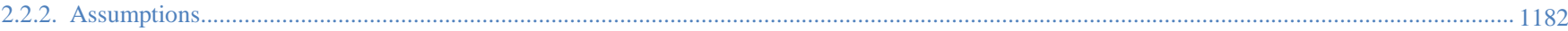

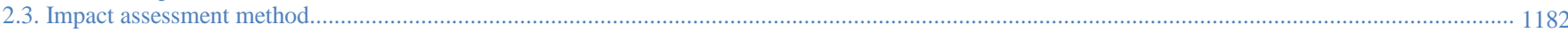

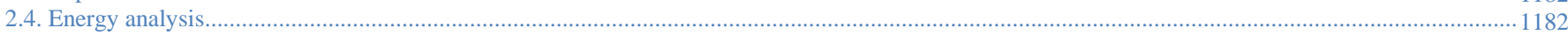

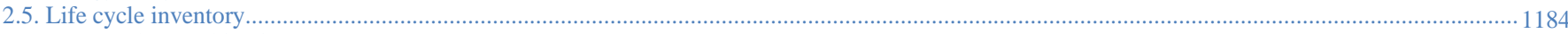

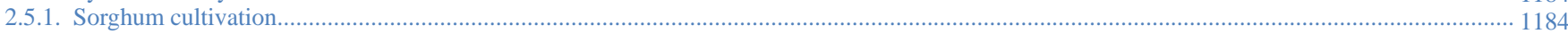

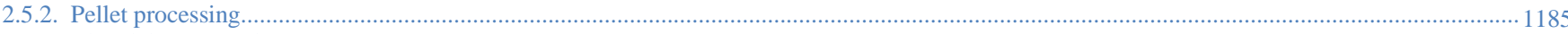

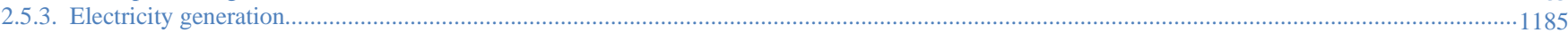

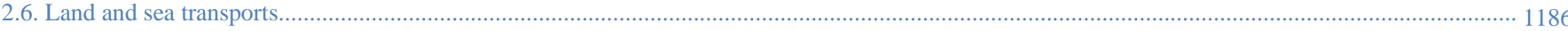

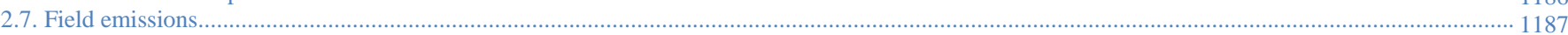

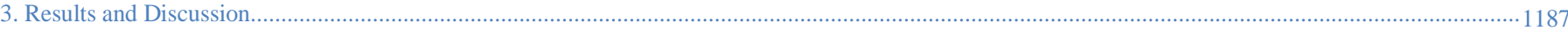

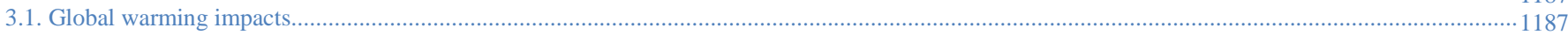

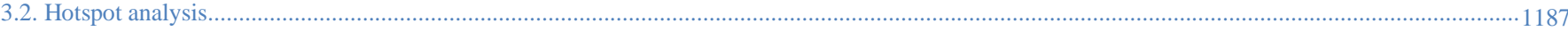

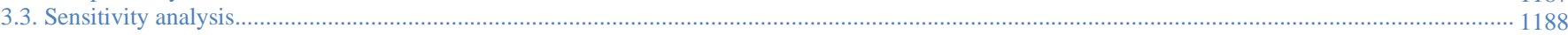

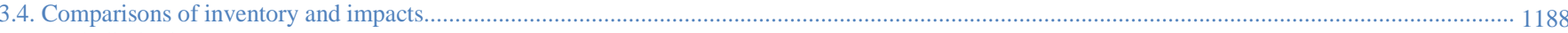

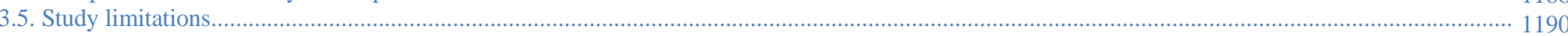

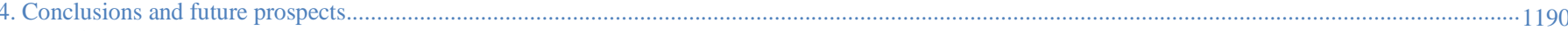

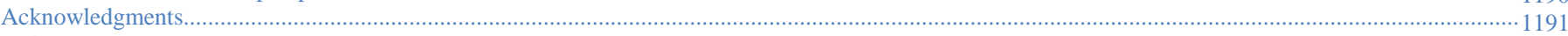

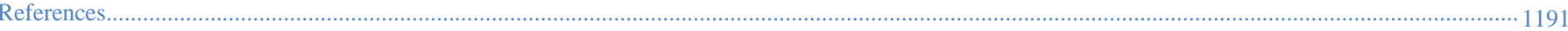

\begin{tabular}{|ll|}
\hline Abbreviations & \\
CF & Co-firing of coal with pellets \\
$\mathrm{CH}_{4}$ & Methane \\
CFB & Continuous fluidized bed \\
FER & Fossil energy ratio \\
FU & Functional unit \\
GCV & Gross calorific value \\
GHG & Greenhouse gas \\
GLO & Global \\
GWP & Global warming potential \\
ID & Indonesia \\
IEA & International Energy Agency \\
IPCC & Intergovernmental Panel on Climate Change \\
ISO & International Organization for Standardization \\
LCA & Life cycle assessment \\
LCDI & Low carbon development initiative \\
LCI & Life cycle inventory \\
LCIA & Life cycle impact assessment \\
LHV & Lower heating value \\
LUC & Land-use change \\
mwd & man work-day \\
NCV & Net calorific value \\
NDC & Nationally determined contributions \\
$\mathrm{N}_{2} \mathrm{O}$ & Dinitrogen monoxide \\
NTT & East Nusa Tenggara \\
PC & Pulverized coal \\
RoW & Rest-of-world \\
SFC & Single-firing of coal \\
SFP & Single-firing of pellets \\
\hline
\end{tabular}

\section{Introduction}

\subsection{The potential and importance of developing bioenergy in Indonesia}

After being stable for three years, global carbon dioxide $\left(\mathrm{CO}_{2}\right)$ emissions from fossil fuel combustion started to rise again, reaching 32.8 billion tons in 2017 (IEA, 2019a). These emissions were largely contributed by the electricity and heat generation sectors $(41 \%)$, followed by transportation (24\%), industry (24\%), and building (8\%) (IEA, 2019a). Coal provided $66.5 \%$ of global electricity and heat production in 2017 (IEA, 2019b). At the global level, China remains the largest coal-consuming country, followed by India and the USA. Indonesia is the $6^{\text {th }}$-largest coal consumer, but exhibits a faster-increasing trend in consumption $(+18.76 \%)$ than any of the aforementioned countries (USA, $-2.9 \%$; China, $+2.9 \%$; and India, $+13.79 \%)$. Moreover, Indonesia has been the largest coal-exporting country since 2017 (IEA, 2019b).

According to Indonesia's state-owned electricity company, the energy mix in Indonesia is still dominated by fossil fuels, including coal (59.9\%), natural gas (22.3\%), and crude oil (6\%) (PLN, 2019). However, the Indonesian government has set an optimistic target of adopting $23 \%$ renewable energy by 2025 (MEMR, 2019). This will partly be achieved by replacing old coal power plants with renewable energy plants, with a total capacity of over 11,000 MW (Reuters, 2020). At present, however, energy from biomass remains marginal, as hydropower (53\%) and geothermal $(44 \%)$ are the dominating sources of renewable energy in Indonesia (PLN 2019). This is largely due to the higher monetary costs of bioenergy compared to those of other renewables and coal as well (Bappenas, 2019).

Global consumption of wood pellets by the energy and heating sectors increased by around $60 \%$ between 2010 and 2016, reaching approximately 30 million tons in 2016 (IEA, 2017). The major markets were the European Union, North America, Japan, and Korea (IEA, 2017). Considering its extensive land resources and high primary productivity, Indonesia has the potential to become a major pellet producer to meet domestic and global demands (Hidayat, 2009). 


\subsection{The Indonesian government's climate commitments}

In 2017, Indonesia launched the Low Carbon Development Initiative (LCDI) to fulfill commitments to addressing the global issue of climate change (Bappenas, 2019). The most conservative scenario is to meet its unconditional Nationally Determined Contributions (NDC) target of 29\%-lower emissions in 2030 compared to the baseline scenario (no intervention), based on the reference year of 2017. To implement the policy, the government issued the Ministry of Energy and Mineral Resources Regulation No. 50 of 2017 concerning the utilization of renewable energy sources for electricity supply. In the context of this development, collaboration with local governments is needed to provide sufficient land for biomass production and to create supporting regulations regarding biofuel prices (MEMR, 2018a). One way of facilitating the rapid development of Indonesia's biomass energy industry is to utilize marginal land resources for planting energy crops.

\subsection{Marginal land and the potential of biomass production in Flores}

Marginal land is defined as any land characterized by lower productivity mainly due to poor soil quality, undesirable climatic conditions, high erodibility, or other environmental risks, thus being less suitable for cultivating field crops (Gelfand et al., 2013). According to the Ministry of Environment and Forestry, Indonesia has approximately 14 million ha of marginal land in total (MoEF, 2018).

East Nusa Tenggara (NTT) is the southernmost province, located in the eastern part of Indonesia. Forest cover in NTT was estimated at only $9.6 \%$ of the land area (Russel-Smith et al., 2007). As one of the major islands comprising NTT, Flores hosts approximately 400,000 ha of marginal land (BPDASHL Benain Noelmina, 2018), mostly has not been utilized and predominantly covered by grassland savannas (Russell-Smith et al., 2007). It exhibits diverse physiographic conditions, ranging from wavy to hilly to sloped lands (Matheus et al., 2017). Cultivating sorghum, as an energy crop, in these areas is very potential, considering its adaptability to marginal conditions
(Gelfand et al., 2013; Mulyani et al., 2013; Qu et al., 2014; Sainju et al., 2015). Figure 1 provides an illustration of the marginal land distribution in Flores. Further details on marginal land distribution in Indonesia and Flores can be found in Table S1 and Table S2, respectively (Supplementary Information)

NTT, including Flores, receives less rainfall than other areas in Indonesia (Mulyani et al., 2013; Kurniawan and Yuniati, 2015; BPS NTT, 2020). The soil of Flores is derived from volcanic material such as Haplustepts and Haplustolls (Mulyani et al., 2013). For areas in Flores with a specific climate $(<1,000 \mathrm{~mm}$ annual rainfall) and soil conditions $(<50 \mathrm{~cm}$ soil depth), Mulyani et al. (2013) recommended the cultivation of adaptable crops, including sorghum.

Types of fuel used in a power plant should match with combustion technologies. Pulverized coal (PC) combustion and continuous fluidized bed (CFB) combustion are conventional technologies employed in coalfired power plants in Indonesia (Khaerunisa et al., 2009). Detailed descriptions of the types of coal power plant technologies commonly used in Indonesia can be found in Table S3 (Supplementary Information).

Criteria for the solid fuel (coal or biomass pellets) for different types of power plant technologies are summarized in Table S4 (Supplementary Information) (Stromberg, 2006). According to these criteria, sorghum pellets are technically feasible for combustion in both PC or CFB power plants. The use of pellets as a substitute for coal in a power plant can be enabled either by retrofitting existing power plants to a co-firing system (combustion of coal together with biomass) or by refurbishing the plant such that it can be entirely operated on pellets (Morrison and Golden, 2017). A brief overview of the studies on the application of biomass co-firing in various power plant technologies can be found in Table S5 (Supplementary Information).

\subsection{Issues of coal and pellet combustion in power plants}

PC is the standard technology for coal-fired electricity generation,

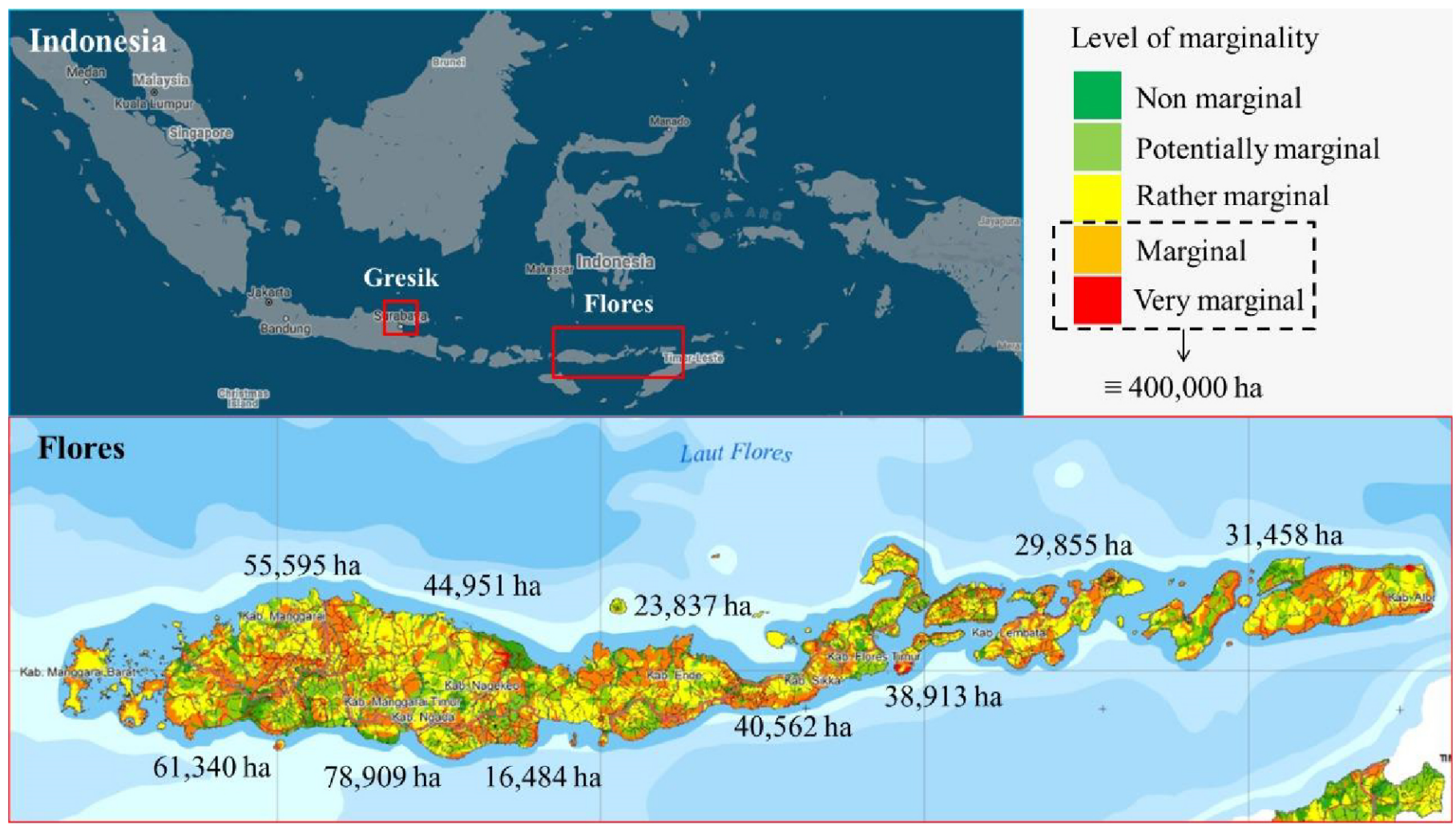

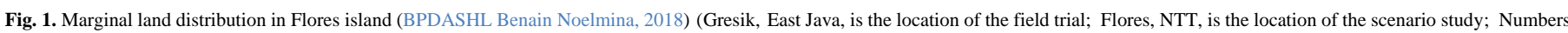
indicate area of marginal and very-marginal lands in Flores). 
accounting for over 95\% of the total global capacity (Lockwood, 2013). In comparison with pulverized fuel, circulating fluidized bed combustion, which is a configuration of fluidized bed combustion technology, enables better control of emissions and higher fuel flexibility (Aho et al., 2013). Power plants operating on PC (Dunaievska et al., 2016) and CFB (Aho et al., 2013) technologies could, however, be applied to a co-firing system, thus making it possible to reduce greenhouse gas (GHG) emissions.

Trial co-firing under both combustion types has taken place at several coal power plants in Indonesia (MEMR, 2020). For example, the Jeranjang power plant (25 MW), with CFB combustion technology, has realized the co-firing of coal with domestic waste pellets (Fadli et al., 2019). The Indramayu coal-fired power plant $(330 \mathrm{MW})$, with PC technology, has realized co-firing with 5\% wood pellets (Husaini, 2020).

The formation of slagging (on furnace walls) or fouling (on convective surfaces, such as the superheater) deposits is a fundamental issue related to the ash content in coal power plant technologies (Demirbas, 2004; Miller, 2004). Coals used in thermal power plants generally contain ash levels ranging from $8 \%$ to as high as $55 \%$ (on an as-received basis) (Bhatt, 2006). For herbaceous biomass, such as grass (including sorghum), the high contents of alkali metals (such as $\mathrm{Na}$ and $\mathrm{K}$ ) and chlorine results in ash with a low melting point which promotes the formation of corrosive deposits (Lockwood, 2013). Furthermore, the alkali-chloride deposits act as a glue, making it hard to clean (Aho et al., 2013). When the biomass is pulverized in a PC power plant, the fibrous parts of the biomass can also accumulate over time (Lockwood, 2013). Moreover, pellet dust creates a fire hazard that is potentially disruptive to the automated feeding system (Mostafa et al., 2019). In a CFB power plant, however, solid fuel is only crushed just before being fed into the boiler, and no grinding mills are required.

\subsection{Life cycle assessment for scenario modeling}

According to the ISO standard (ISO 14040, 2006), life cycle assessment (LCA) is a tool for evaluating potential environmental impacts throughout a product's life cycle, from raw material acquisition through production, use, end-of-life treatment, recycling, and final disposal (i.e., cradle-to-grave). By covering the entire life cycle of a product system, LCA can avoid potential burden-shifting. Also, it can cover several impact categories which promotes holistic solutions.

A recent literature review conducted by Barros et al. (2019), indicated that the number of studies on LCA of electricity has been increasing considerably, focusing mostly on reducing GHG emissions to mitigate climate change through the replacement of fossil fuels by renewable ones.

The current study is in line with the global trend as it considers the potential reductions in the impacts of global warming through the use of renewable energy. In addition, the current study provides key information needed by the Indonesian Government to support public policy toward developing bioenergy to substitute fossil fuels.

There have been several prior LCA studies on the benefits of substituting fossil energy sources with pellets made from grasses. None of these involved sorghum, but rather used miscanthus (Lewandowski et al., 1995; Murphy et al., 2013) and switchgrass (Bergman et al., 2015). In addition to not including power plant infrastructures, Lewandowski et al. (1995) and Bergman et al. (2015) did not model the incomplete combustion of biomass either. Bergman et al. (2015) also did not consider field emissions stemming from fertilizer application. These inventories (infrastructure, incomplete combustion, and field emission) could potentially contribute to the emission of important GHGs such as $\mathrm{N}_{2} \mathrm{O}$ and $\mathrm{CH}_{4}$. Hence, excluding these parameters in the models is likely to increase deviation from reality. In this context, the current study contributes to this research topic in the following way. It is the first LCA study on electricity generation by sorghum pellets that managed to overcome previous modeling gaps by carrying out a sensitivity analysis in consideration of the aforementioned parameters.

\subsection{Formulation of the research questions}

This study presents an effort to reduce GHG emissions from the energy sector in Indonesia. We carried out a scenario study by developing an LCA model of the utilization of marginal land in Flores for sorghum cultivation, and the utilization of its biomass for electricity generation. Implementation of $100 \%$ biomass firing (single-firing of biomass) for electricity generation is technically possible (Morrison and Golden, 2017). However, since infrastructure and policies for $100 \%$ biomass firing applications have not been established on a commercial scale in Indonesia (MEMR, 2019), co-firing applications in existing coal power plants were considered to be more practical. Further, this scheme could reduce the capital and operational costs of generating renewable electricity (Boylan, 1996). However, the risk of increased ash deposition on boilers and other surfaces due to the biomass needs to be sufficiently addressed (Livingston, 2016).

To this end, the general objective of this study was to evaluate the potential GHG savings in coal electricity generation by co-firing with sorghum pellets using LCA. The co-firing biomass electricity ratio was set at $5 \%$, considering that a co-firing ratio of up to $10 \%$ would not cause serious technical problems (Sondreal et al., 2001). This study also quantified the complete replacement of coal with biomass to illustrate the maximum potential GHG savings. The above objective was broken down into the following specific research questions:

Q1. What quantity of sorghum pellets corresponds to the energy content of 1 ton of coal?

$Q 2$. What is the fossil energy ratio (FER) of sorghum pellets?

Q3. How much pellets are required to generate 5,300 GWh electricity via $5 \%$ co-firing in all coal-fired power plants in Indonesia?

Q4. What extent of GHG-emission reductions could be expected if the pellets were used for 5\% co-firing in all coal-fired power plants in Indonesia?

Q5. What are the effects of considering incomplete biomass combustion and field emissions from fertilizer application on the final results?

The paper is presented by first evaluating sorghum cultivation in fields, biomass processing in pellet factories, and electricity generation in power plants. Further, energy analysis and global warming impacts are evaluated for the pellet product and the generated electricity. The global warming impacts of electricity generation are then calculated by assuming complete combustion of biomass and no field emissions from fertilizer application, herein representing the reference scenario. Finally, a sensitivity analysis is carried out by considering the two important aforementioned parameters, herein referred to as the alternative scenarios.

\section{Methodology}

Available marginal land in Flores is approximately 400,000 ha. However, some areas are very unlikely to be utilized, for example, because the area is too steep. Thus, a conservative approach was taken in this study, assuming that only $25 \%$ of the marginal lands $(100,000 \mathrm{ha})$ is a flat area where sorghum cultivation is possible. Further detail is available in Table 1 and Table S2 (Supplementary Information). Sorghum for energy production is classified as either sweet or biomass-type (Ameen et al., 2017). Our study used the latter, while producing only small amounts of grain and sweet juice. In LCA, this is considered as a mono-functional system, producing only biomass. For this reason, allocation (Suh et al., 2010) or substitution (Weidema, 2000) procedures were not explored further.

Two transportation modes were included in this study, i.e., land transport (sorghum field to pellet factory to port), and sea transport (port to power plants). In the modeling, the loss of sorghum biomass or pellet product due to production or transport was assumed to be negligible. The pellets were used to substitute coal for the generation of electricity in all coal-fired power plants in Indonesia in a co-firing system.

Indonesian annual coal electricity production in 2017 was $105,651 \mathrm{GWh}$ (MEMR, 2018b). This amount was used for the baseline case. The scenario model did not consider the trajectory for future models, as discussed by Döll et al. (2008), but rather used a specific point in time, namely 2017. To determine the GHG savings of various scenarios, we developed an LCA model using SimaPro 9.0 for electricity generation in different combustion systems: single-firing of coal (SFC), co-firing of coal with pellets (CF), and single-firing of pellets (SFP).

It should be noted that the co-firing ratio was based on energy values, i.e., $5 \%$ from sorghum pellets and $95 \%$ from coal. GHG savings represent the difference in global warming impacts between scenario models (CF and $\mathrm{SFP}$ ) and the baseline model (SFC). As indicated previously, the CF model 
Table 1.

Descriptions of assumptions used in this study.

\begin{tabular}{ll}
\hline Assumption & Description \\
\hline Agricultural conditions ${ }^{*}$ & $\begin{array}{l}\text { Sorghum cultivation scenarios in Flores use agricultural data } \\
\text { from Gresik, East Java (Indonesia), assuming similarities in } \\
\text { soil fertility and regional climate. }\end{array}$ \\
& $\begin{array}{l}\text { The marginal land area available in Flores is approximately } \\
\text { 400,000 ha. We use a conservative approach, assuming that } \\
\text { only 25\% of the marginal lands (100,000 ha) is a flat area } \\
\text { cultivation }\end{array}$ \\
where sorghum cultivation is possible. \\
"The carbon sequestered by biomass through photosynthesis \\
is considered equal to the carbon feedstock in wood that is \\
eventually released throughout its life cycle" (Head et al., \\
2019). \\
Burning of sorghum pellets in a power plant assumes \\
complete combustion (i.e., no CH ${ }_{4}$ and N $\mathrm{N}_{2} \mathrm{O}$ emissions). \\
Field emission
\end{tabular}

*The context of assumptions was varied in the sensitivity analysis (see Section 3.4).

has been tested at several power plants and will be expanded to others in Indonesia, while the SFP model was included only to illustrate the maximum potential of GHG savings. To summarize, the overall LCA models in this study were developed by first creating a baseline model, followed by the reference scenarios and the alternative scenarios, as shown in Figure 2.

\subsection{Goal and scope definition}

An attributional LCA was carried out to compare three electricity product systems. Their system boundaries were cradle-to-gate covering fuel production, transport, and electricity generation. Figure 3 shows the system boundaries of the three product systems using the same functional unit (FU), 1 $\mathrm{kWh}$ of electricity produced. The foreground and background systems in each product system were identified.

\subsection{Data source and assumption}

\subsubsection{Data source}

Primary data used in this study included sorghum cultivation and pellet processing data collected from a field trial at PT Kaliandra Merah, a woodbased pellet processing facility located in Gresik, East Java (Indonesia). Inventory for electricity production was based on Widiyanto et al. (2003), and flow quantities were adjusted to obtain more representative conditions. For coal data, we used secondary data from the ecoinvent database. Data of sorghum and pellets transports were obtained from assumed locations of sorghum fields and pellet factories, while coal transport used the default ecoinvent dataset. The coal transport is treated as a background system, meaning it does not represent a specific condition, but generic. Emissions from fuel combustion in the foreground system were calculated based on emission factors from the IPCC (2006a). Detail emission factors can be found in Table S6 (Supplementary Information).

We used the ecoinvent database version 3.5 (Wernet et al., 2016) to develop input and output flows in the background system. The "market" category was selected for datasets in the background system, such as fertilizer, electricity, and diesel. This does not represent specific conditions, but rather reflects a generic model (Wernet et al., 2016). However, it is quite relevant considering that this study aims to find a general picture of potential GHG savings by the LCA method in Indonesia. The geographical priority for the ecoinvent dataset selection, consecutively, was Indonesia (ID), rest-ofworld (RoW), and global (GLO). The ecoinvent datasets used to represent the inventory in this study are compiled in Table S7 (Supplementary Information).

\subsubsection{Assumptions}

ISO 14044 regulates assumptions used in LCA studies. Assumptions will produce uncertainties, so the results of the study analysis should be accompanied by a sensitivity analysis to reach robust conclusions. This is particularly important if the conclusions are to be used for providing recommendations (ISO 14044, 2006). In this study, sensitivity analyses were carried out in certain situations, i.e., if emissions due to nitrogenous fertilizer application $\left(\mathrm{N}_{2} \mathrm{O}\right)$ and incomplete combustion of biomass in a power plant $\left(\mathrm{CH}_{4}\right.$ and $\left.\mathrm{N}_{2} \mathrm{O}\right)$ were considered in the model. Sorghum pellets are considered carbon-neutral, so the $\mathrm{CO}_{2}$ released through combustion at the power plant was assumed zero net $\mathrm{CO}_{2}$ emissions. The concept of carbon-neutral is an issue that is still being debated (Wiloso et al., 2016; Head et al., 2019). Considering a broad system boundary covering sorghum cultivation, pellet processing, transport, and electricity generation, we simplified the model using the carbon-neutral assumption. This same approach was used by a number of prior LCA studies on biopellet, including García et al. (2019), Lewandowski et al. (1995), Murphy et al. (2013), Nian (2016), Schakel et al. (2014), Yang et al. (2019). Table 1 summarizes the assumptions used in this study.

\subsection{Impact assessment method}

The impact category considered in this study was global warming (midpoint impact). To calculate the global warming impact of each product, we used the CML-IA baseline 3.5 method. There are 183 types of emissions identified as impact indicators for the global warming category according to this method. The characterization factor followed the principles developed by the Intergovernmental Panel on Climate Change (IPCC) 2013 with a 100-year time horizon (GWP 100a). This assessment method, by default, excludes biogenic carbon emissions as an impact indicator. This study also did not consider the global warming impacts associated with land-use change (LUC). Even if LUC was considered, it would have minimal impact in the case of the conversion of marginal land into cropland or grassland (Bergman et al., 2015; Daystar et al., 2015), such as sorghum field.

\subsection{Energy analysis}

In this study, an energy analysis was carried out on sorghum pellets using FER index, following the same approach used by Pradhan et al (2010) and Rajaeifar et al. (2013). FER is defined as the ratio of the energy content of the product over the primary fossil fuel inputs (Zaimes et al., 2013). FER is calculated through Equation 1, and values greater than 1 indicate net energy positive, reflecting more energy in the pellet products than the fossil energy consumed during production (Zaimes et al., 2013). The heating value that is pertinent to the power plant, according to this study, was based on the lower heating value (LHV) or net calorific value (NCV). The reason for this is that we assumed that the power plant under study does not use a heat recovery system, such that the latent heat of vaporization of water in the reaction products is not recovered (Lee, 2015). Thus, to calculate the total primary energy used for pellet processing, we used the "Cumulative Energy Demand (LHV) V1.00" method (Weidema et al., 2013). The method distinguishes primary energy types into eight categories, including non-renewable resources (fossil, nuclear, and primary forest) and renewable resources (biomass, wind, solar, geothermal, and water) (Frischknecht et al., 2007).

$F E R=\frac{\text { Energy content in sorghum pellet }}{\text { Primary fossil energy input }}$ 


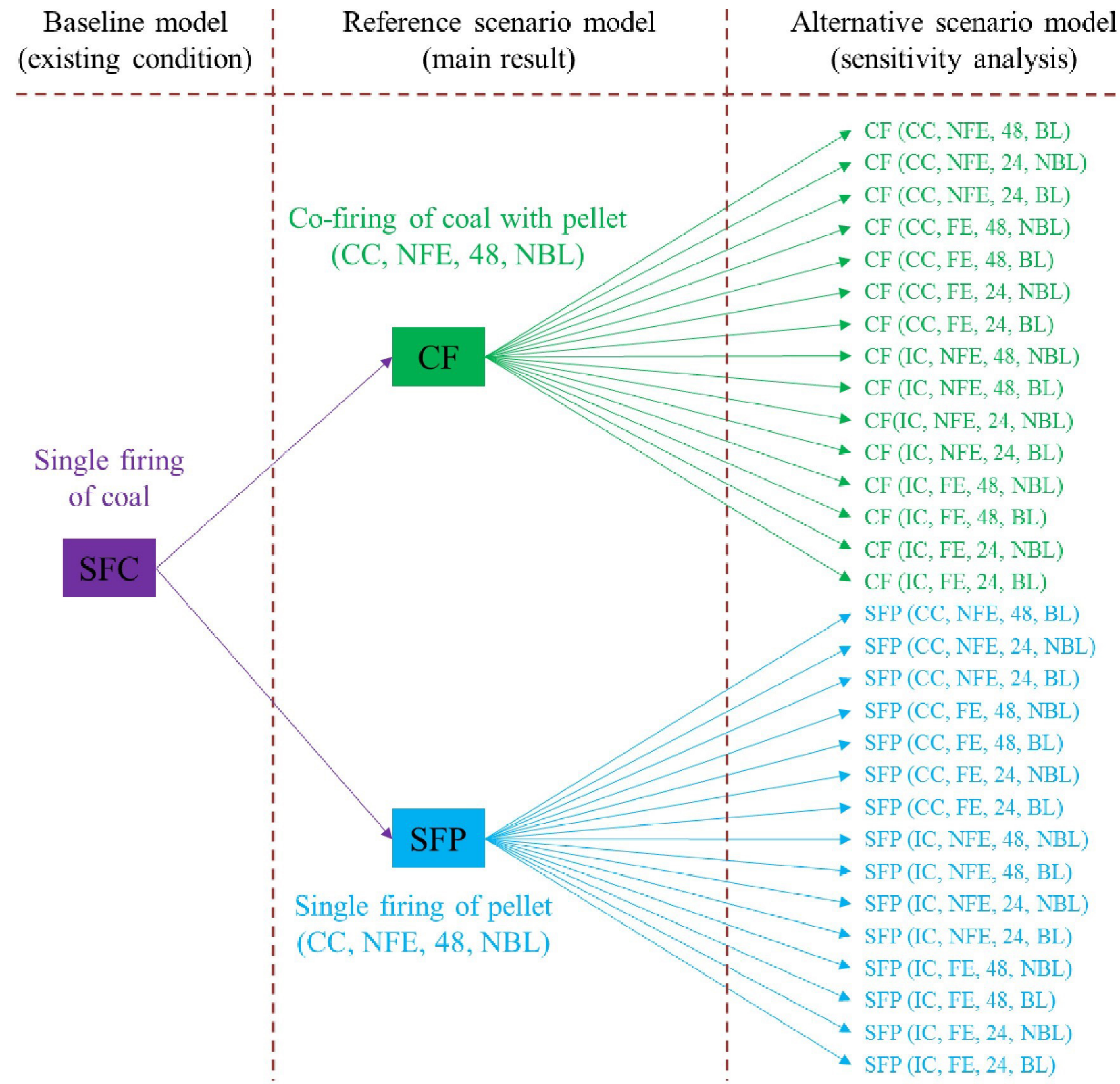

Fig. 2. The overall LCA models developed in this study.

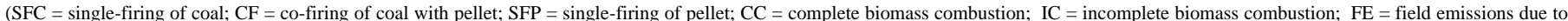

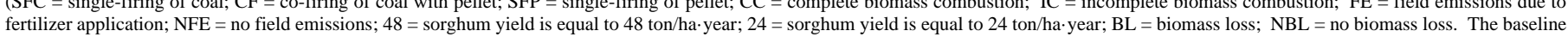

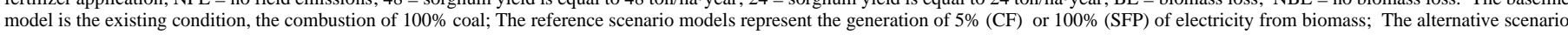
models are for the sensitivity analysis, considering variations in combustion conditions and field emissions).

The heating value of pellets was obtained from primary data through chemical analysis, while the heating value of coal was obtained based on the average value in Indonesia, both on an as-received basis (Miller, 2004; Lee, 2015). Table 2 shows the chemical analysis of the pellets produced in pelletprocessing facilities in Gresik; more detailed results are given in Table S8 (Supplementary Information).
According to the Ministry of National Development Planning of Indonesia (Bappenas, 2016), coal reserves in Indonesia are dominated (approximately 60\%) by coal with a medium calorific value of 5,100-6,100 $\mathrm{kcal} / \mathrm{kg}$. However, $80 \%$ of the coal produced is exported to other countries, while the remaining coal of lower quality $(<5,100 \mathrm{kcal} / \mathrm{kg})$ is destined for domestic consumption. Details on domestic coal consumption between 


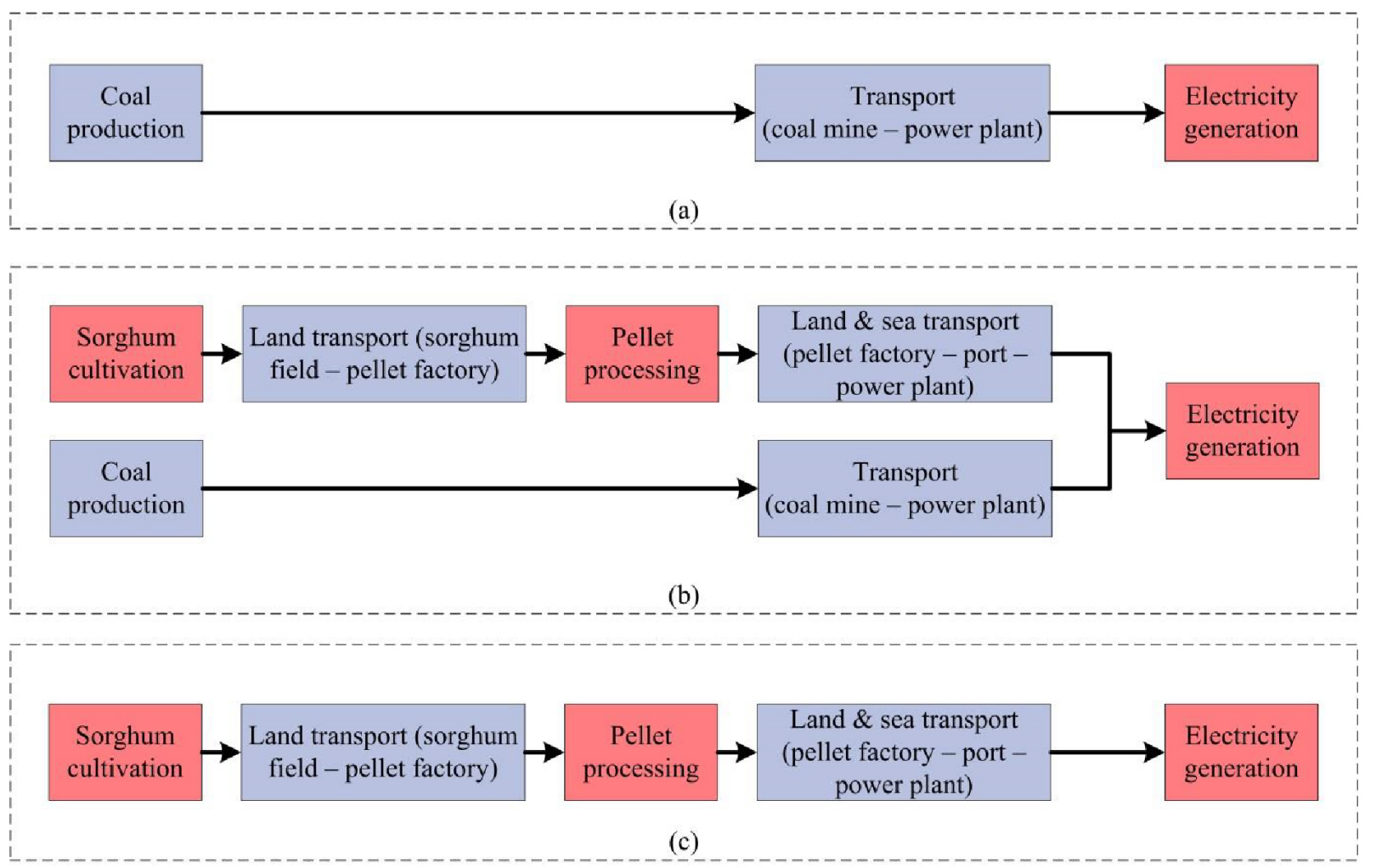

Foreground system

Background system

Fig. 3. System boundaries of the compared product systems

(a) single-firing of coal (SFC); (b) co-firing of coal with pellet (CF); and (c) single-firing of pellet (SFP).

Table 2.

Chemical analysis of the sorghum pellets produced in Gresik, East Java.

\begin{tabular}{lc}
\hline Parameter & Value (as-received) \\
\hline Ash (wt.\%) & 7.28 \\
Carbon (wt.\%) & 45.61 \\
Hydrogen (wt.\%) & 5.18 \\
Nitrogen (wt.\%) & 0.36 \\
Oxygen (wt.\%) & 37.84 \\
Sulfur (wt.\%) & 0.09 \\
Total moisture (wt.\%) & 3.64 \\
\hline Gross calorific value (kcal/kg) & $4,156^{*}$ \\
\hline
\end{tabular}

*4,156 kcal/kg = 17.4 MJ/kg (Ansermet and Brechet, 2018).

2013 and 2018 are given in Table S9 (Supplementary Information). This study used the average gross calorific value (GCV) of coal used in Indonesian power plants, i.e., 4,600 kcal $/ \mathrm{kg}$ or $19.3 \mathrm{MJ} / \mathrm{kg}$ (Bappenas, 2016). Based on the calorific value, it is classified as lignite (hereafter referred to as brown coal) according to the IEA classification system (IEA, 2019c). Brown coal is the typical coal used in power plants in Indonesia. Table 3 summarizes the pellet and brown coal requirements in the power plant.

There was a slight decrease in the gross efficiency value due to differences in the NCV between pellets and brown coal (Beér, 2007; Schakel et al., 2014). Based on the amount of each fuel required to generate electricity in a power plant, $1 \mathrm{~kg}$ of brown coal can be replaced by $1.12 \mathrm{~kg}$ of sorghum pellets.

\subsection{Life cycle inventory \\ 2.5.1. Sorghum cultivation}

The product system of sorghum was divided into five stages: land processing, planting, fertilizing, maintenance, and harvesting. Primary data for sorghum cultivation was taken from a field trial in Gresik, East Java (Indonesia). Table 4 shows the inventory of sorghum cultivation with a reference flow of $1 \mathrm{ha} \cdot \mathrm{yr}$, yielding 48 tons of dry sorghum biomass/ha.yr based on data from the field trial in Gresik. Thus, the total annual production of sorghum for an area of 100,000 ha is 4.8 million tons, assuming there is no mass loss during sorghum harvesting. However, to be more realistic, a 7\% mass loss was also considered in the sensitivity analysis.

The sorghum yield considered in this study (48 ton/ha.yr) is rather high compared to those reported in literature, i.e., 43 ton/ha·yr (Qu et al., 2014) 
Table 3.

Fuel requirements for a power plant

\begin{tabular}{lccccc}
\hline Type of fuel & $\begin{array}{c}\text { Energy content } \\
(\mathbf{M J} / \mathbf{k g})\end{array}$ & \multicolumn{2}{c}{$\begin{array}{c}\text { Power plant efficiency } \\
(\boldsymbol{\%})\end{array}$} & \multirow{2}{*}{$\begin{array}{c}\text { Fuel } \\
\text { requirements } \\
(\mathbf{k g} / \mathbf{k W h})\end{array}$} \\
\cline { 2 - 5 } & $\mathbf{G C V}^{\mathbf{a}}$ & $\mathbf{N C V}^{\mathbf{b}}$ & Gross & Net & \\
\hline Brown coal & 19.26 & 18.30 & 36.1 & 38.0 & 0.518 \\
Pellet & 17.40 & 16.40 & 35.8 & 38.0 & 0.578 \\
\hline
\end{tabular}

${ }^{a}$ Brown coal GCV (Bappenas, 2016). GCV of pellets was obtained from the chemical analysis in Table 2.

${ }^{b}$ Net calorific value (NCV) of brown coal is $5 \%$ lower than its GCV (IEA, 2004). NCV of pellets $=\mathrm{GCV}-\left[\left(212 \times \mathrm{X}_{\mathrm{H}}\right)+\left(0.8 \times\left(\mathrm{X}_{\mathrm{O}}+\mathrm{X}_{\mathrm{N}}\right)\right] \times(1-0.01 \mathrm{M}) \times 24.5 \mathrm{M}\right.$, where $\mathrm{X}_{\mathrm{H}}, \mathrm{X}_{\mathrm{O}}, \mathrm{X}_{\mathrm{N}}$, and $M$ are percentages of hydrogen, oxygen, nitrogen, and moisture, respectively (Lee, 2015).

Table 4.

Life cycle inventory of 1 ha. yr sorghum at various cultivation stages.

\begin{tabular}{|c|c|c|c|c|}
\hline Cultivation stage & Flow & Direction & Amount & Unit \\
\hline \multirow{6}{*}{ Land processing } & Compost & Input & 5 & ton \\
\hline & Manpower & Input & 80 & $\mathrm{mwd}^{\mathrm{b}}$ \\
\hline & Diesel $^{\mathrm{a}}$ & Input & 134 & $\mathrm{~L}$ \\
\hline & $\mathrm{CO}_{2}$ & Output & 358 & $\mathrm{~kg}$ \\
\hline & $\mathrm{CH}_{4}$ & Output & $4.78 \mathrm{E}-2$ & $\mathrm{~kg}$ \\
\hline & $\mathrm{N}_{2} \mathrm{O}$ & Output & $9.56 \mathrm{E}-3$ & $\mathrm{~kg}$ \\
\hline \multirow{8}{*}{ Planting } & Sorghum seed & Input & 30 & $\mathrm{~kg}$ \\
\hline & Nitrogen fertilizer & Input & 200 & $\mathrm{~kg}$ \\
\hline & Phosphate fertilizer & Input & 150 & $\mathrm{~kg}$ \\
\hline & Potassium fertilizer & Input & 15 & $\mathrm{~kg}$ \\
\hline & Furadan (pesticide) & Input & 5 & $\mathrm{~kg}$ \\
\hline & Decis (pesticide) & Input & 2 & $\mathrm{~L}$ \\
\hline & Water, from well & Input & 20,000 & $\mathrm{~L}$ \\
\hline & Manpower & Input & 60 & $\operatorname{mwd}^{\mathrm{b}}$ \\
\hline \multirow{3}{*}{ Fertilizing } & Nitrogen fertilizer ${ }^{\mathrm{c}}$ & Input & 150 & $\mathrm{~kg}$ \\
\hline & Phosphate fertilizer ${ }^{\mathfrak{c}}$ & Input & 150 & $\mathrm{~kg}$ \\
\hline & Potassium fertilizer ${ }^{\mathrm{c}}$ & Input & 150 & $\mathrm{~kg}$ \\
\hline \multirow{5}{*}{ Maintenance } & Manpower & Input & 190 & $\mathrm{mwd}^{\mathrm{b}}$ \\
\hline & Diesel $^{\mathrm{a}}$ & Input & 100 & liter \\
\hline & $\mathrm{CO}_{2}$ & Output & 267 & $\mathrm{~kg}$ \\
\hline & $\mathrm{CH}_{4}$ & Output & $3.57 \mathrm{E}-2$ & $\mathrm{~kg}$ \\
\hline & $\mathrm{N}_{2} \mathrm{O}$ & Output & $7.14 \mathrm{E}-3$ & $\mathrm{~kg}$ \\
\hline Harvesting & Manpower & Input & 140 & $\operatorname{mwd}^{\mathrm{b}}$ \\
\hline
\end{tabular}

The unit 'ton' refers to a metric ton ( 1 metric ton $=1,000 \mathrm{~kg}$ ).

${ }^{\mathrm{a}}$ Emission factors $=7.48 \mathrm{E}-2 \mathrm{~kg} \mathrm{CO} / \mathrm{MJ} ; 10 \mathrm{E}-6 \mathrm{~kg} \mathrm{CH}_{4} / \mathrm{MJ} ; 2 \mathrm{E}-6 \mathrm{~kg} \mathrm{NO}_{2} / \mathrm{MJ}$ (IPCC, 2006a). The density and energy content (NCV) of the diesel used in this study were $0.83 \mathrm{~kg} / \mathrm{L}$ and 43 $\mathrm{MJ} / \mathrm{kg}$, respectively (Jungbluth et al., 2018).

${ }^{\mathrm{b}} \mathrm{mwd}=$ man work-day is defined as work done by one person in one day (eight hours) (Wahyuni, 2014).

${ }^{c}$ Nitrogen fertilizer $=$ urea; Phosphate fertilizer $=$ TSP $($ Triple super phosphate); Potassium fertilizer $=\mathrm{KCl}$ (Potassium chloride)

and 17.4-42.1 ton/ha·yr (Tang et al., 2018). This value was in fact obtained from fertile soil in Gresik. In contrast, the sites in Flores is marginal and its annual precipitation is much lower (Mulyani et al., 2013) than Gresik. These drawbacks are very likely to affect the sorghum yield. Thus, a sensitivity analysis was carried out considering a sorghum yield of $24 \mathrm{ton} / \mathrm{ha} \cdot \mathrm{yr}$.

According to Khoshnevisan (2013), a one-hour human labor energy input is equivalent to $1.96 \mathrm{MJ}$. Therefore, a one mwd (man work-day, $8 \mathrm{~h} / \mathrm{d}$ ) is equal to 15.68 MJ. In total, energy derived from human labor for $1 \mathrm{ha} \cdot \mathrm{yr}$ of sorghum cultivation is equivalent to $7,369.6 \mathrm{MJ}(15.68 \mathrm{MJ} / \mathrm{mwd} \times 470 \mathrm{mwd})$. Some flow quantities expressed in units of volume were converted to units of mass using a conversion factor from the literature (NCBI, 2004 and 2014; Jungbluth et al., 2018), as SimaPro tends to use units of mass as reference quantities. There was no dataset for sorghum seed in the ecoinvent database. Instead, we used "market for wheat seed, for sowing GLO" to represent sorghum seed, as both belong to a grass family.

\subsubsection{Pellet processing}

This study assumed no sorghum loss due to the transport and pellet processing, such that all sorghum crops were converted $100 \%$ into pellets. To be more practical, this study also considered $10 \%$ of mass loss during pellet processing in the sensitivity analysis. Primary data for pellet processing factors such as electricity, diesel, lubricating oil, and grease were taken from a field trial in Gresik. Table 5 shows the life cycle inventory (LCI) for processing 1 ton of pellets. The current study used the same datasets for grease and lubricating oil, adopting the same approach conducted by Elduque et al. (2015).

The infrastructure models for a pellet factory referenced the ecoinvent dataset "market for wood pellet factory GLO," assuming a lifespan of 40 years. This was a conservative estimate, as the ecoinvent dataset "wood pellet production RoW" uses a life span of 50 years (Wernet et al., 2016). Based on a production trial of 85 tons of pellet/d and 24 working $\mathrm{d} / \mathrm{month}$, the annual production capacity of sorghum pellets was 24,000 ton/yr. Electricity input used the dataset "market for electricity, medium voltage ID" to represent the average electricity mix in Indonesia. The pelleting step consumed the highest portion of electricity (37\%), followed by pre-grinding (22\%), fine-grinding (16\%), and drying (13\%). Details of the electricity inputs for pellet processing can be found in Table S10 (Supplementary Information).

Table 5.

Life cycle inventory of 1 ton of pellets in the production stage.

\begin{tabular}{|c|c|c|c|}
\hline Flow & Direction & Amount & Unit \\
\hline Sorghum & Input & 1 & ton \\
\hline Pellet factory ${ }^{a}$ & Input & $1.04 \mathrm{E}-6$ & piece $^{\mathrm{b}}$ \\
\hline Electricity & Input & 148.67 & $\mathrm{kWh}$ \\
\hline Lubricating oil & Input & 0.012 & $\mathrm{~L}$ \\
\hline Grease & Input & 0.050 & $\mathrm{~L}$ \\
\hline Diesel $^{\mathrm{c}}$ & Input & 0.774 & $\mathrm{~L}$ \\
\hline $\mathrm{CO}_{2}$ & Output & 2.07 & $\mathrm{~kg}$ \\
\hline $\mathrm{CH}_{4}$ & Output & $2.76 \mathrm{E}-4$ & $\mathrm{~kg}$ \\
\hline $\mathrm{N}_{2} \mathrm{O}$ & Output & $5.52 \mathrm{E}-5$ & $\mathrm{~kg}$ \\
\hline Waste mineral oil & Output & 0.062 & $\mathrm{~L}$ \\
\hline
\end{tabular}

The unit 'ton' refers to a metric ton ( 1 metric ton $=1,000 \mathrm{~kg}$ ).

${ }^{\text {a }}$ Refer to the ecoinvent dataset.

${ }^{\mathrm{b}}$ Unit for the infrastructure for a pellet factory. One piece $=$ total pellet processing during the life span of the infrastructure $(24,000$ ton/year $\times 40$ years $=960,000$ ton). One-ton pellet processing requires only $1 / 960,000$ piece of infrastructure, which is $1.04 \mathrm{E}-6$ piece.

${ }^{\mathrm{c}}$ Emission factors $=7.48 \mathrm{E}-2 \mathrm{~kg} \mathrm{CO} / \mathrm{MJ} ; 10 \mathrm{E}-6 \mathrm{~kg} \mathrm{CH} / 4 / \mathrm{MJ} ; 2 \mathrm{E}-6 \mathrm{~kg} \mathrm{NO} / \mathrm{MJ}$ (IPCC, 2006a). The density and energy content (NCV) of the diesel used in this study were $0.83 \mathrm{~kg} / \mathrm{liter}$ and $43 \mathrm{MJ} / \mathrm{kg}$, respectively (Jungbluth et al., 2018).

\subsubsection{Electricity generation}

Table 6 shows the inventories for $1 \mathrm{kWh}$ electricity generated from different combustion systems. The inventory is based on inventory data of the Suralaya power plant in Banten (Widiyanto et al., 2003) which uses PC combustion technology; details can be found in Table S11 (Supplementary Information). The infrastructure model for a power plant referenced the "market for hard coal GLO power plant" dataset from the ecoinvent. It consisted of a mix of $500 \mathrm{MW}-(72 \%)$ and $100 \mathrm{MW}-(28 \%)$ capacity power plants. This did not represent the specific distribution of coal-fired power plants in Indonesia (see Table S12; Supplementary Information). Since the infrastructure of the coal power plant contributes lesser impacts than those of the operational stage (Atilgan and Azapagic, 2015), we considered that the choice of the dataset was not problematic. The characteristics of power plant infrastructure shown in Table 6 are based on the following parameter values: (i) lifespan of 37.5 years; (ii) 4,000 operating hours/yr; (iii) $500 \mathrm{MW}$ power plant capacity; and (iv) capacity factor of 0.7 . The values of parameters (i), (ii), and (iii) were taken from the ecoinvent dataset "electricity production, hard coal RoW" (Wernet et al., 2016), while the capacity factor of 0.7 was added by the authors as a conservative assumption. 
Table 6.

Life cycle inventory of $1 \mathrm{kWh}$ electricity for different product systems.

\begin{tabular}{|c|c|c|c|}
\hline Flow & Direction & Amount $^{\mathrm{a}}$ & Unit \\
\hline \multicolumn{4}{|c|}{ SFC $(\text { single-firing of coal })^{b}$} \\
\hline Lime & Input & 0.007 & $\mathrm{~kg}$ \\
\hline Limestone & Input & 0.093 & $\mathrm{~kg}$ \\
\hline Power plant & Input & $1.90 \mathrm{E}-11$ & piece \\
\hline $\mathrm{Coal}^{\mathrm{c}}$ & Input & 0.518 & $\mathrm{~kg}$ \\
\hline $\mathrm{CO}_{2}$ & Output & 1.09 & $\mathrm{~kg}$ \\
\hline $\mathrm{CH}_{4}$ & Output & $2.84 \mathrm{E}-5$ & $\mathrm{~kg}$ \\
\hline $\mathrm{N}_{2} \mathrm{O}$ & Output & 4.74E-5 & $\mathrm{kg}$ \\
\hline Ash (coal) & Output & 0.138 & $\mathrm{~kg}$ \\
\hline \multicolumn{4}{|c|}{$C F$ (co-firing of coal with pellet) } \\
\hline Lime & Input & 0.007 & $\mathrm{~kg}$ \\
\hline Limestone & Input & 0.093 & $\mathrm{~kg}$ \\
\hline Power plant & Input & $1.90 \mathrm{E}-11$ & piece \\
\hline Pellet & Input & 0.029 & $\mathrm{~kg}$ \\
\hline Coal & Input & 0.492 & $\mathrm{~kg}$ \\
\hline $\mathrm{CO}_{2}$ & Output & 1.04 & $\mathrm{~kg}$ \\
\hline $\mathrm{CH}_{4}$ & Output & $2.70 \mathrm{E}-5$ & $\mathrm{~kg}$ \\
\hline $\mathrm{N}_{2} \mathrm{O}$ & Output & $4.50 \mathrm{E}-5$ & $\mathrm{~kg}$ \\
\hline Ash (coal) & Output & 0.131 & $\mathrm{~kg}$ \\
\hline Ash (pellet) & Output & $2.17 \mathrm{E}-3$ & $\mathrm{~kg}$ \\
\hline \multicolumn{4}{|c|}{ SFP (single-firing of pellet) } \\
\hline Lime & Input & 0.008 & $\mathrm{~kg}$ \\
\hline Limestone & Input & 0.103 & $\mathrm{~kg}$ \\
\hline Power plant & Input & $1.90 \mathrm{E}-11$ & piece \\
\hline Pellet & Input & 0.578 & $\mathrm{~kg}$ \\
\hline Ash (pellet) & Output & 0.043 & $\mathrm{~kg}$ \\
\hline
\end{tabular}

The unit 'ton' refers to a metric ton ( 1 metric ton $=1,000 \mathrm{~kg}$ ).

a Amount of coal $(\mathrm{kg} / \mathrm{kWh})$ in this study was obtained through calculations based on PLN Indonesia statistical data for 2017 (MEMR, 2018b), while the amounts of other materials in the SFP model were adjusted proportionally to changes in the amount of coal.

b Source: Widiyanto et al. (2003)

${ }^{\mathrm{c}}$ Emission factors $=1.15 \mathrm{E}-1 \mathrm{~kg} \mathrm{CO} / \mathrm{MJ} ; 3 \mathrm{E}-6 \mathrm{~kg} \mathrm{CH} / \mathrm{MJ} ; 5 \mathrm{E}-6 \mathrm{~kg} \mathrm{~N}_{2} \mathrm{O} / \mathrm{MJ}$ (IPCC, 2006a).

The energy content $(\mathrm{NCV})$ of the coal used in this study was $18.3 \mathrm{MJ} / \mathrm{kg}$ (see Table 3 ).

\subsection{Land and sea transports}

Only domestic land and sea transport were considered in this study, with ton-kilometer $(\mathrm{t} \cdot \mathrm{km})$ as the functional unit. These were differentiated into three transportation models: (I) land transport of sorghum biomass from fields to pellet factories; (II) land transport of sorghum pellets from factories to the Marapokot port; and (III) sea transport of sorghum pellets from the Marapokot port to coal-fired power plants. The datasets used for land and sea transport in this study were "market for transport, freight, lorry 16-32 metric ton, EURO3 RoW" and "market for transport, freight, sea, transoceanic ship GLO," respectively. The selection of datasets for land transport represented a conservative approach, considering that the "EURO3" category has a higher emission level than the other EURO categories (Simons, 2016).

Figure 4 shows the assumed locations of sorghum cultivation and pellet factories. Sorghum fields totaling 100,000 ha were modeled, along with their distribution over Flores Island. Each green marker represents 5,000 ha for each of the 20 sorghum fields, while the locations of the 4 pellet factories are represented by the black markers. This results in a ratio of 1:5 for the number of pellet factories to sorghum fields. Therefore, to process all harvested sorghum biomass from five sorghum fields into pellets (at a ratio of $1: 1$ for sorghum input and pellet output), each pellet factory must have a capacity of 1.2 million tons of sorghum annually $(50 \times 24,000$ ton/yr, see Section 2.5.2). Infrastructure calculations were carried out linearly (Weidema et al., 2013) to simplify the model, i.e., each pellet factory in Figure 4 represents 50 factories under real conditions.

The average distance of land transport section (I) was $20 \mathrm{~km}$, and the yields from each sorghum field were assumed to be similar, i.e., 240,000 tons (48 ton/ha. $\mathrm{yr} \times 5,000 \mathrm{ha}$ ). By multiplying the two parameters (load and distance), a transport value of 4.8 million $\mathrm{t} \cdot \mathrm{km}$ was obtained. Thus, the total for transport from the 20 sorghum fields to pellet mills is 96 million $\mathrm{t} \cdot \mathrm{km}$.

The land transport section (II) utilized stockpiles at the Marapokot port. A stockpile was modeled as a dummy inventory to store the pellets for further shipping to all coal-fired power plants in Indonesia. Various distance and transport values of the pellets from the pellet factories to the port (in $\mathrm{t} \cdot \mathrm{km}$ ) are given in Table S13 (Supplementary Information)

This study assumed that the pellets transported by ships reach the power plant without any additional transport, considering that almost all power plants are either located near seaports or supported with port facilities (IEA Clean Coal Centre, 2016).

Details regarding the number of pellets distributed via sea routes (from the port to coal power plants) can be found in Table S14 (Supplementary Information). The distribution of pellets to the power plant was modeled using "transoceanic ship" datasets. This is typically used for transporting bulk materials such as coal through sea routes. The quantity of pellets needed for each power plant varied, and was calculated based on the actual annual production of coal electricity in 2017, rather than on the production capacity (see Table S15; Supplementary Information). The transportation value of pellets from the port to power plants were expressed in two values: $0.04 \mathrm{t} \cdot \mathrm{km} / \mathrm{kWh}$ for $\mathrm{CF}$ and $0.8 \mathrm{t} \cdot \mathrm{km} / \mathrm{kWh}$ for SFP. It should be noted that the $t \cdot \mathrm{km}$ value for SFP was derived from the $\mathrm{t} \cdot \mathrm{km}$ value for CF divided by 0.05 , the co-firing ratio applied. An illustration of pellet

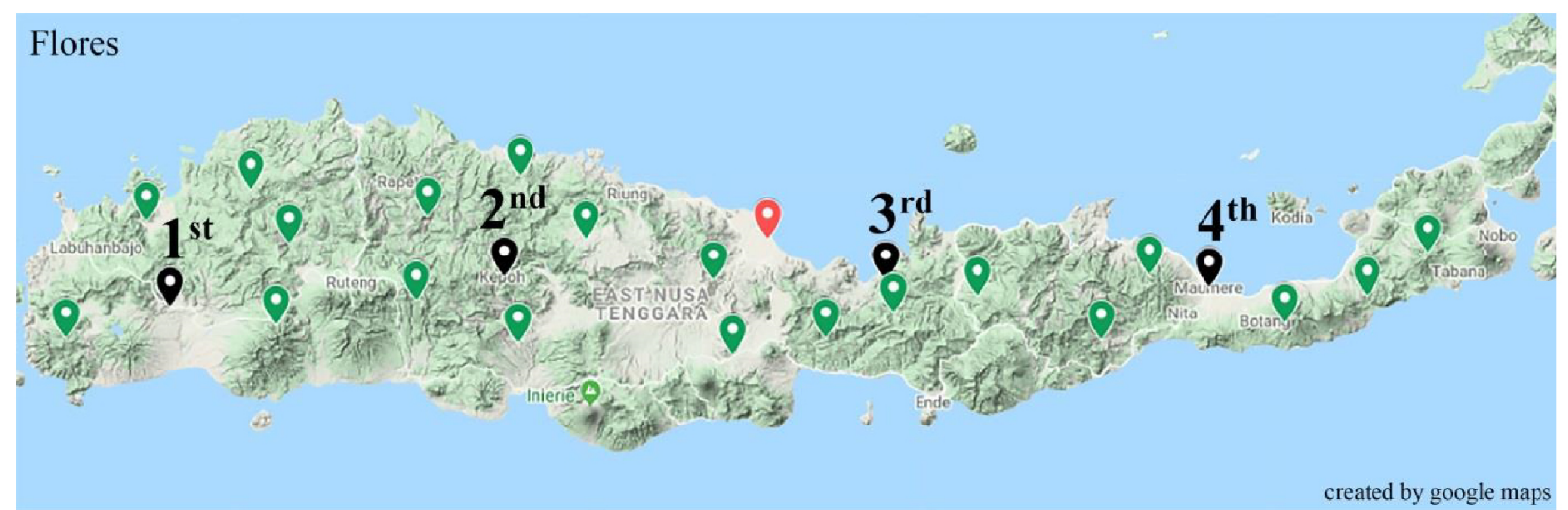

Sorghum field $\mathbf{O}$ Pellet factory

Port (Marapokot)

Fig. 4. Assumed locations of sorghum fields and pellet factories.

Please cite this article as: Wiloso E.I., Setiawan A.A.R., Prasetia H., Muryanto, Wiloso A.R., Subyakto, Sudiana I.M., Lestari R., Nugroho S., Hermawan D., Fang K., Heijungs R. Production of sorghum pellets for electricity generation in Indonesia: A life cycle assessment. Biofuel Research Journal 27 (2020) 1178 1194. DOI: 10.18331/BRJ2020.7.3.2 
distribution via sea routes can be seen in Figure S1 (Supplementary Information).

\subsection{Field emissions}

Field emissions are considered an important issue in agricultural activities, and mainly consist of $\mathrm{CH}_{4}$ and $\mathrm{N}_{2} \mathrm{O}$ emissions primarily due to anaerobic processes and the application of nitrogenous fertilizers (van Amstel and Swart, 1994). In that regard, we also considered these emissions in the sensitivity analysis. Methane emissions are likely to occur under strictly anaerobic conditions (Oertel et al., 2016), such as a wet system in a rice field (Chen et al., 2011). As sorghum cultivation typically does not involve a submerged system, anaerobic conditions are unlikely to be present. Consequently, $\mathrm{CH}_{4}$ emissions should be very low, such that it can be ignored. In this context, Murphy et al. (2013), who studied the LCA of miscanthus, a grass plant similar to sorghum, did not consider $\mathrm{CH}_{4}$ emissions either.

Besides originating from artificial or compost fertilizers, $\mathrm{N}_{2} \mathrm{O}$ emissions in managed soil are also derived from urine, crop residues, and soil organic matter (Brentrup et al., 2000). In the current study, we used the IPCC guidelines to calculate $\mathrm{N}_{2} \mathrm{O}$ field emissions (IPCC, 2006b). Due to lack of data on other parameters, only direct $\mathrm{N}_{2} \mathrm{O}$ emissions and those from $\mathrm{N}$ inputs to managed soil were considered. The nitrogen contents of the synthetic fertilizer and compost were around 50\% (field-trial in Gresik, East Java) and 2\% (Kim et al., 2014), respectively. Based on the calculations (see detail in Table S16; Supplementary Information), the field emission value was $4.09 \mathrm{~kg} \mathrm{~N}_{2} \mathrm{O} / \mathrm{ha} \cdot \mathrm{yr}$. This would certainly give a lower amount of $\mathrm{N}_{2} \mathrm{O}$ field emissions than the ideal method, i.e., including both direct and indirect $\mathrm{N}_{2} \mathrm{O}$ emissions from all sources. However, the total $\mathrm{N}_{2} \mathrm{O}$ emissions from an agricultural field are generally dominated by direct $\mathrm{N}_{2} \mathrm{O}$ emissions, which contributes approximately $75 \%$ of total $\mathrm{N}_{2} \mathrm{O}$ emissions (Cavigelli et al., 2012). Thus, the sensitivity analysis related to field emissions from agricultural activities captures the major aspects of concern. In addition to $\mathrm{N}_{2} \mathrm{O}$ emissions, $\mathrm{CO}_{2}$ emissions from the application of $\mathrm{N}$ fertilizer (urea) were also considered in the sensitivity analysis using the method recommended by the IPCC (2006b), which value was $257 \mathrm{~kg}$ $\mathrm{CO}_{2} /$ ha. yr.

Besides $\mathrm{N}$ fertilizer application, land modification can also be a significant contributor to the global warming impact, as soil carbon is released into the atmosphere (Baker et al., 2007). In this regard, Robertson et al. (2017) indicated that proper cultivation management techniques is a key factor to improve soil carbon accumulation. For example, in sorghum cultivation, the cover cropping techniques with hairy vetch/rye wheat could increase soil carbon (Sainju et al., 2015). However, GHG emissions associated with soil carbon is outside the scope of the current study, and not discussed any further herein.

\section{Results and Discussion}

\subsection{Global warming impacts}

The global warming impacts of electricity generation were evaluated for the SFC, CF, and SFP product systems. GHG savings were determined by subtracting the values of the scenario models (CF or SFP) from the baseline model (SFC). Table 7 summarizes the results of the global warming impacts of electricity generated by the three product systems, and the GHG savings associated with the CF and SFP scenarios.

Table 7 shows that pellet production based on 100,000 ha $y r$ is 4.8 million tons. Meanwhile, the total amount of pellets needed for 5\% co-firing in all coal power plants in Indonesia is only 3.05 million tons. Under these conditions, there will thus be an excess of 1.75 million tons of pellets annually. We further elaborated the results presented in Table 7 to determine which life cycle stages contributed the most to the global warming impacts by conducting a hotspot analysis. The results for each product system are shown in Table 8 .

Assuming 100\% conversion of harvested sorghum biomass into pellets, the total annual production volume of pellets was 4.8 million tons, which represents 83.5 million GJ of potential energy (based on GCV). Furthermore, if the pellets are sent to power plants, they could generate 29.9 million GJ or 8,309.34 GWh electricity (based on a gross efficiency of 35.8\%).

For the purpose of calculating FER index, the energy of the pellets and the primary fossil energy required for their production were expressed on an NCV basis. The energy required to produce the pellets was calculated via the "cumulative energy demand (LHV) V1.00/cumulative energy demand" method
Table 7.

The global warming impacts of electricity for different product systems and functional units.

\begin{tabular}{|c|c|c|c|c|c|}
\hline \multirow{2}{*}{$\begin{array}{l}\text { Product } \\
\text { system }^{\mathrm{a}}\end{array}$} & \multicolumn{2}{|c|}{ Fuel requirement $(\mathrm{kg})$} & \multirow{2}{*}{$\begin{array}{l}\text { Global warming } \\
\quad\left(\mathrm{kg} \mathrm{CO} \mathrm{CO}_{2}-\mathrm{eq}\right)\end{array}$} & \multicolumn{2}{|c|}{ GHG savings ${ }^{\mathrm{c}}$} \\
\hline & Coal & Pellet & & $\mathrm{kg} \mathrm{CO}_{2}$-eq & $\%$ \\
\hline \multicolumn{6}{|c|}{ Functional unit $(\mathrm{FU})=1 \mathrm{kWh}$ electricity $^{\mathrm{d}}$} \\
\hline SFC & 0.518 & 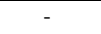 & 1.12 & - & - \\
\hline $\mathrm{CF}$ & 0.492 & 0.029 & 1.07 & 0.05 & 4 \\
\hline SFP & - & 0.578 & 0.17 & 0.95 & 85 \\
\hline \multicolumn{6}{|c|}{$\overline{F U}=8,309.34$ GWh electricity (utilizing 100,000 ha.yr field) } \\
\hline $\begin{array}{l}\text { SFC } \\
\end{array}$ & $4.30 \mathrm{E} 9$ & - & $9.31 \mathrm{E} 9$ & - & - \\
\hline $\mathrm{CF}$ & $4.09 \mathrm{E} 9$ & $2.40 \mathrm{E} 8$ & $8.89 \mathrm{E} 9$ & $4.15 \mathrm{E} 8$ & 4 \\
\hline SFP & - & $4.80 \mathrm{E} 9$ & $1.39 \mathrm{E} 9$ & $7.92 \mathrm{E} 9$ & 85 \\
\hline \multicolumn{6}{|c|}{$\overline{\mathrm{FU}}=105,651.39 \mathrm{GWh}$ electricity (1-year coal-based electricity production in Indonesia } \\
\hline SFC & $5.47 \mathrm{E} 10$ & - & $1.18 \mathrm{E} 11$ & & . \\
\hline $\mathrm{CF}^{\mathrm{e}}$ & $5.20 \mathrm{E} 10$ & $3.05 \mathrm{E} 0$ & $1.13 \mathrm{E} 11$ & $5.28 \mathrm{E} 09$ & 4 \\
\hline SFP & - & $6.10 \mathrm{E} 10$ & $1.76 \mathrm{E} 10$ & $1.01 \mathrm{E} 11$ & 85 \\
\hline
\end{tabular}

${ }^{a} \mathrm{SFC}=$ single-firing of coal; $\mathrm{CF}=$ co-firing of coal with pellet; $\mathrm{SFP}=$ single-firing of pellets (see Section 2.1).

${ }^{\mathrm{b}}$ Considering complete combustion of pellets in power plants, and not considering field emissions from sorghum cultivation activities.

${ }^{\mathrm{c}}$ The reference scenario for reducing global warming is SFC

${ }^{\mathrm{d}}$ The result of this functional unit is illustrated in Figure 5 .

${ }^{\mathrm{e}}$ Implementing 5\% co-firing in all existing coal power plants in Indonesia requires 3.05 million tons of pellets and reduces the global warming impacts by 5.28 million ton $\mathrm{CO}_{2}$-eq from the baseline of 118 million ton $\mathrm{CO}_{2}$-eq over a year (4\% GHG savings).

Table 8.

Contribution of life cycle stages to global warming impacts for different product systems.

\begin{tabular}{|c|c|c|}
\hline Life cycle stage of product system & $\begin{array}{l}\text { Global warming } \\
(\mathrm{kg} \mathrm{CO} 2 \mathrm{eq} / \mathrm{kWh})\end{array}$ & $\begin{array}{c}\text { Contribution } \\
(\%)\end{array}$ \\
\hline \multicolumn{3}{|l|}{ SFC (single-firing of coal) } \\
\hline Coal production $^{\mathrm{a}}$ & 0.014 & 1.26 \\
\hline Electricity generation & 1.106 & 98.74 \\
\hline \multicolumn{3}{|l|}{ CF (co-firing of coal with pellet) } \\
\hline Coal production & 0.013 & 1.25 \\
\hline Pellet production ${ }^{\mathrm{b}}$ & 0.008 & 0.76 \\
\hline Electricity production & 1.050 & 97.99 \\
\hline \multicolumn{3}{|l|}{ SFP (single-firing of sorghum pellet) } \\
\hline Sorghum production & 0.036 & 21.62 \\
\hline Land transport $(\mathrm{I})^{\mathrm{c}}$ & 0.002 & 1.15 \\
\hline Pellet processing & 0.100 & 59.89 \\
\hline Land transport (II) ${ }^{\mathrm{d}}$ & 0.016 & 9.40 \\
\hline Sea transport ${ }^{\mathrm{e}}$ & 0.009 & 5.58 \\
\hline Electricity generation & 0.004 & 2.36 \\
\hline
\end{tabular}

${ }^{\mathrm{a}}$ Includes coal transport from mining areas

${ }^{\mathrm{b}}$ Includes sorghum cultivation and biomass transport

${ }^{\mathrm{c}}$ Sorghum biomass from fields to pellet factory

${ }^{\mathrm{d}}$ Pellet product from factories to ports

${ }^{\mathrm{e}}$ Pellet product from ports to power plants

(Weidema et al., 2013), which was conducted with SimaPro. The results showed that the production of 1 ton of sorghum pellets (16.4 GJ) required $2.85 \mathrm{GJ}$ of fossil energy. Hence, the FER of sorghum pellets was 5.75 .

\subsection{Hotspot analysis}

Figure 5a illustrates a comparison of the global warming impacts between the three electricity product systems, the values for which were derived from Table 8. It shows that the life cycle stage of electricity generation (orange bar) for the SFP scenario had the lowest global warming impacts $\left(0.167 \mathrm{~kg} \mathrm{CO}_{2}\right.$-eq $\left./ \mathrm{kWh}\right)$ in comparison with those of the SFC and $\mathrm{CF}$ scenarios $\left(1.12 \mathrm{~kg} \quad \mathrm{CO}_{2}-\mathrm{eq} / \mathrm{kWh}\right.$ and $1.07 \quad \mathrm{~kg} \quad \mathrm{CO}_{2}-\mathrm{eq} / \mathrm{kWh}$, respectively). The pellet production under $\mathrm{CF}$ (blue bar in Figure 5a) 
a

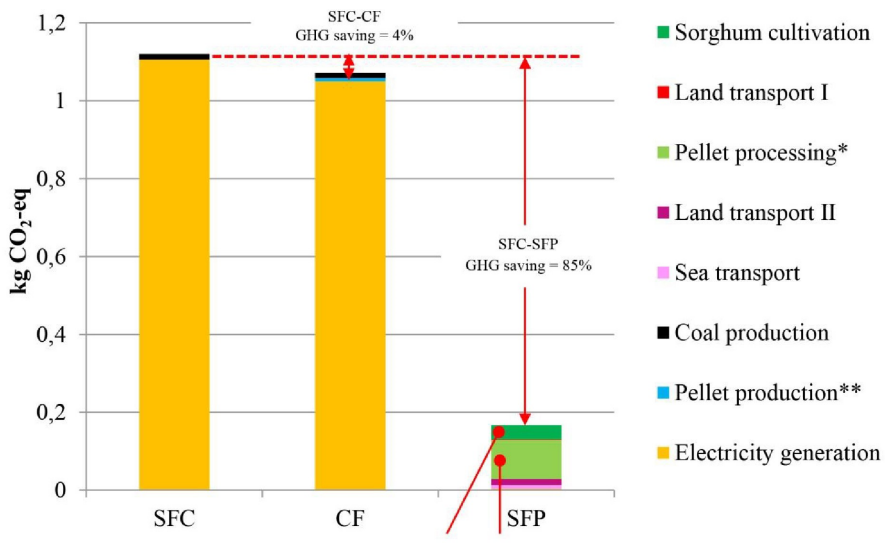

${ }^{*}$ not including sorghum cultivation and transport **including sorghum cultivation and transport

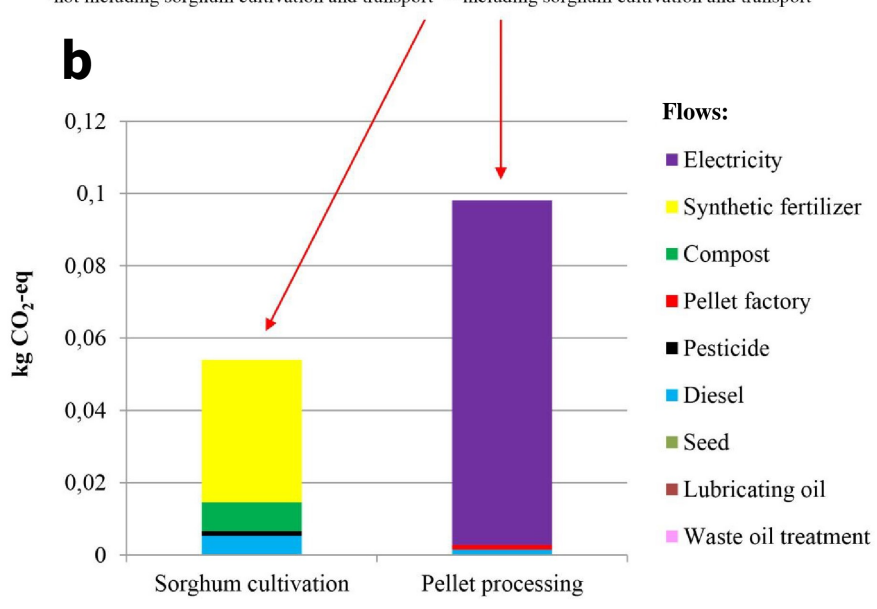

Fig. 5. Hotspot analysis for $1 \mathrm{kWh}$ of electricity generated in different product systems (a) SFC (single-firing of coal), CF (co-firing of coal with pellet), and SFP (single-firing of pellet); (b) Sorghum-cultivation and pellet-processing fractions for SFP.

included upstream processes such as transport and sorghum production, while the pellet processing under SFP (light green bar) did not.

The hotspots for the SFC and CF scenarios were electricity generation, while that for the SFP scenario was pellet processing. The lowest impact of SFP is due to the fact that GHG emissions from pellet combustion were not calculated, following the carbon-neutral principle. The same approach was adopted in other studies on pellets made from grasses such as switchgrass (Bergman et al., 2015) and miscanthus (Lewandowski et al., 1995). Similarly, the GHG emissions from 5\% biomass electricity in the CF scenario were not counted as an impact on global warming. Therefore, in comparison with the SFC scenario, the potential reduction in global warming impacts under the SFP scenario in the current study (SFC-SFP) was 85\%. Meanwhile, Lewandowski et al. (1995) and Bergman et al. (2015) reported more or less similar results, of $90 \%$ and $80 \%$, respectively. Since the CF scenario considers only 5\% electricity production from biomass, the impact reduction under the CF scenario (SFCCF) was proportionally lower (4\%).

Pellet processing shared the largest impact toward global warming, followed by decreasing contributions by sorghum cultivation and electricity generation. The dominant impact of pellet processing over sorghum cultivation is in line with the results obtained in the previous studies (Murphy et al., 2013; Bergman et al., 2015). Figure $\mathbf{5 b}$ shows the relative contributions of sorghum cultivation and pellet processing in SFP systems. It illustrates the contribution of each flow (electricity, fertilizer, pesticide, diesel, and others) to the overall global warming impact.

\subsection{Sensitivity analysis}

As a number of assumptions were made in the modeling, we considered four important issues as the basis for the sensitivity analysis. These were assumptions related to the conditions of the combustion systems (complete or incomplete), field emissions due to fertilizer application, reduced sorghum yield, and biomass loss.

In practice, complete combustion is very rare (van Amstel and Swart, 1994). In spite of that, several studies on grass pellets have also taken this approach to simplify calculations (Lewandowski et al., 1995; Bergman et al., 2015). Concerning field emissions due to fertilizer application, it should be noted that there is an ongoing debate regarding whether or not agricultural land is part of the product system, as it sits at the interface between anthropogenic and environmental systems (Guinée et al., 2002; Goglio et al., 2015). This will lead to differences in LCA modeling directly related to field emissions. For example, Lewandowski et al. (1995) and Murphy et al. (2013) studied miscanthus pellets considering field emissions, while Bergman et al. (2015) did not consider field emissions in their study on switchgrass pellets. Considering marginal land condition and less water input $(10,000$ liter/ha.yr) in large scale operation (100,000 ha), the sorghum yield of $24 \mathrm{ton} / \mathrm{ha} \cdot \mathrm{yr}$ was applied in the sensitivity analysis. A biomass loss of $10 \%$ in sorghum harvesting and $7 \%$ in pellet processing (Jannasch et al., 2001; Murphy et al., 2013; Serra et al., 2017) also underwent the same analysis. Table 9 summarizes the results of the sensitivity analysis.

Based on the results of the sensitivity analysis, the various choices regarding the modeling resulted in GHG savings ranging from $85 \%$ (reference scenario) to $70 \%$ (alternative scenarios) under the SFC-SFP model. However, the GHG savings under the SFC-CF model did not change between the reference and alternative scenarios, after rounding to the nearest whole number. Thus, the CF model was less sensitive than the SFP model to the four modeling choices or assumptions. This is mainly because the co-firing percentage was only $5 \%$. For CF models with higher co-firing ratios (e.g., 10\%), the differences in the estimated GHG savings between the reference and alternative models should be more significant. For illustration, we performed a simulation under the $\mathrm{CF}$ model with a co-firing ratio of $10 \%$, which resulted in GHG savings of $9 \%$ for the reference models and $8 \%$ for all of the alternative models.

\subsection{Comparisons of inventory and impacts}

The current study finds that the global warming impacts of pellet production are higher than those of coal production. However, if the boundary is expanded to include fuel combustion at power plants as well, electricity generated from the pellets becomes "greener" than coal (see Fig. 5). This is mainly due to the carbon-neutral assumption, as biomass has the advantage of zero net $\mathrm{CO}_{2}$ emissions in a combustion process (Sajdak et al., 2019). Figure 5b further indicates that fertilizer and electricity are the hotspots in the sorghum cultivation and pellet processing stages, respectively.

Comparisons with similar LCA studies on pellets produced from grasses, in particular from miscanthus (Lewandowski et al., 1995; Murphy et al., 2013) and switchgrass (Bergman et al., 2015), were conducted to enhance the interpretation of the results. Table 10 summarizes the characteristics of various grass pellets. It shows that sorghum is superior in terms of yield, but has a lower energy content than those produced from miscanthus or switchgrass. Reductions in GHG emissions due to substitution of fossil fuels with pellets were also analyzed by Lewandowski et al. (1995) and Bergman et al. (2015).

We compared the results of this study with those of previous studies on two levels, i.e., life cycle inventory (LCI) and life cycle impact assessment (LCIA). At the LCI level, the comparison was made for those identified as the hotspots in biomass production and pellet processing, i.e., fertilizer and electricity, respectively. To obtain comparable data in the same units, we modified the literature values by considering their specific yield (ton/ha) and energy content $(\mathrm{MJ} / \mathrm{kg})$ as conversion factors. Table 11 shows a comparison of the fertilizer and electricity inputs between the current study and previous studies. As presented, there are considerable differences in the amount of fertilizer applied among the studies considered, but the values of the current study ( $16.98 \mathrm{~kg} /$ ton biomass) and those from Lewandowski et 
Table 9.

Sensitivity analysis on several modeling choices.

\begin{tabular}{|c|c|c|c|c|c|c|c|c|}
\hline \multicolumn{4}{|c|}{ Choice in modeling } & \multicolumn{3}{|c|}{$\begin{array}{c}\text { Global warming } \\
\left(\mathrm{kg} \mathrm{CO}_{2} \text {-eq/kWh) }\right.\end{array}$} & \multicolumn{2}{|c|}{ GHG saving (\%) } \\
\hline Combustion conditions & Field emissions $^{\mathrm{a}}$ & $\begin{array}{c}\text { Sorghum yield } \\
\text { (ton/ha·yr) }\end{array}$ & Mass loss & SFC & CF & SFP & SFC-CF & SFC-SFP \\
\hline \multirow{8}{*}{ Complete $^{\mathrm{b}}$} & \multirow{4}{*}{ No } & \multirow{2}{*}{48} & No & 1.12 & 1.07 & 0.171 & 4 & 85 \\
\hline & & & Yes & 1.12 & 1.07 & 0.186 & 4 & 83 \\
\hline & & \multirow{2}{*}{24} & No & 1.12 & 1.07 & 0.207 & 4 & 82 \\
\hline & & & Yes & 1.12 & 1.08 & 0.229 & 4 & 80 \\
\hline & \multirow{4}{*}{ Yes } & \multirow{2}{*}{48} & No & 1.12 & 1.07 & 0.187 & 4 & 83 \\
\hline & & & Yes & 1.12 & 1.07 & 0.206 & 4 & 82 \\
\hline & & \multirow{2}{*}{24} & No & 1.12 & 1.08 & 0.239 & 4 & 79 \\
\hline & & & Yes & 1.12 & 1.08 & 0.268 & 4 & 76 \\
\hline \multirow{8}{*}{ Incomplete $^{c}$} & \multirow{4}{*}{ No } & \multirow{2}{*}{48} & No & 1.12 & 1.08 & 0.235 & 4 & 79 \\
\hline & & & Yes & 1.12 & 1.08 & 0.250 & 4 & 78 \\
\hline & & \multirow{2}{*}{24} & No & 1.12 & 1.08 & 0.271 & 4 & 76 \\
\hline & & & Yes & 1.12 & 1.08 & 0.294 & 4 & 74 \\
\hline & \multirow{4}{*}{ Yes } & \multirow{2}{*}{48} & No & 1.12 & 1.08 & 0.251 & 4 & 78 \\
\hline & & & Yes & 1.12 & 1.08 & 0.270 & 4 & 76 \\
\hline & & \multirow{2}{*}{24} & No & 1.12 & 1.08 & 0.303 & 4 & 73 \\
\hline & & & Yes & 1.12 & 1.08 & 0.332 & 4 & 70 \\
\hline
\end{tabular}

$\mathrm{SFC}=$ single-firing of coal; $\mathrm{CF}=$ co-firing of coal with pellet; $\mathrm{SFP}=$ single-firing of sorghum pellet (see Section 2.1).

${ }^{\text {a }}$ Considered $\mathrm{CO}_{2}$ and $\mathrm{N}_{2} \mathrm{O}$ emissions. The reason for not including $\mathrm{CH}_{4}$ field emission has been explained in Section 2.7 .

${ }^{b}$ There are no $\mathrm{CH}_{4}$ and $\mathrm{N}_{2} \mathrm{O}$ emissions from sorghum pellet combustion at the power plant.

${ }^{c}$ There are $\mathrm{CH}_{4}$ and $\mathrm{N}_{2} \mathrm{O}$ emission from sorghum pellet combustion at the power plant.

Table 10.

Comparison of the characteristics of various grass pellets.

\begin{tabular}{lcccc}
\hline Parameter & This study & $\begin{array}{c}\text { Lewandowski } \\
\text { et al. (1998) }\end{array}$ & $\begin{array}{c}\text { Murphy } \\
\text { et al. (2013) }\end{array}$ & $\begin{array}{c}\text { Bergman } \\
\text { et al. (2015) }\end{array}$ \\
\hline Type of grass biomass & Sorghum & Miscanthus & Miscanthus & Switchgrass \\
Yield (ton/ha) & 48 & 20 & 11.5 & 13.9 \\
$\begin{array}{l}\text { Harvest efficiency } \\
\text { Net yield (ton/ha) }\end{array}$ & 1 & 1 & 0.9 & 1 \\
Production site & Indonesia & Germany & Ireland & $\begin{array}{c}\text { Southeast } \\
\text { USA }\end{array}$ \\
$\begin{array}{l}\text { Energy content }(\mathrm{MJ} / \mathrm{kg})^{\mathrm{b}} \\
\begin{array}{l}\text { Energy equivalency } \\
\text { (kg pellet/kg coal) }\end{array}\end{array}$ & 16.4 & 18.6 & 18 & 18 \\
\hline
\end{tabular}

${ }^{a}$ Ratio between actual and potential biomass harvest.

${ }^{\mathrm{b}}$ All based on the net caloric value (NCV).

${ }^{\mathrm{c}}$ Refers to the brown coal used in this study, with an energy content of $18.3 \mathrm{MJ} / \mathrm{kg}$ (see Table 3).

al. (1995) (17.5 kg/ton biomass) are quite similar. Meanwhile, Bergman et al. (2015) considered the application of only $5.26 \mathrm{~kg}$ of fertilizer. In summary, the ratio of fertilizer used in the studies listed in Table 11, from left to right, is approximately $3: 3: 2: 1$. Sorghum has a high absorption efficiency for nitrogenous fertilizers (Ameen et al., 2017). Further, as indicated in Section 1.3, marginal land is characterized by low fertility, leading to higher fertilizer requirements in order to produce the same amount of biomass. Since sorghum is cultivated on marginal land in this study, soil fertility is likely to be the dominant controlling factor.

Like in the current study, Murphy et al. (2013) and Bergman et al. (2015) also found that electricity is the input flow that contributes the most to the global warming impacts of pellet processing. Referring to Table 11, the ratio of electricity used among the studies considered, from left to right, is approximately $3: 2: 1: 3$. The amount of electricity required for the production of 1 ton of pellets in this study was $148.67 \mathrm{kWh}$, which is nearly the same as the $145.67 \mathrm{kWh}$ reported in the study by Bergman et al. (2015).

In 2017, the proportion contributed by coal to the electricity mix in Indonesia was 58\% (PLN, 2018), while those in the United States and Europe were $14 \%$ (Eurostat, 2019; U.S. Energy Information Administration, 2019). Rather than referring to PLN (2018), our model considered an energy mix that differed from the actual conditions. We used the ecoinvent dataset "market for electricity, medium voltage ID" to represent the average electricity mix in Indonesia, which consists of approximately $46 \%$ lignite (brown coal), followed by natural gas and oil. Meanwhile, Bergman et al. (2015) used an electricity input of the eastern US grid mix between 2008 and 2010, consisting of approximately 58\% coal, followed by decreasing contributions by nuclear energy and natural gas. Since Bergman et al. (2015) considered electrical energy with a similar energy mix, their results should be comparable with those of the current study. Table 12 compares the global warming impacts among the

Table 11.

Comparison of fertilizer and electricity inputs of various grass pellets.

\begin{tabular}{lcccc}
\hline \multirow{2}{*}{ Flow } & This study & Lewandowski et al. (1995) & Murphy et al. (2013) & Bergman et al. (2015) \\
\cline { 2 - 5 } & Sorghum & Miscanthus & Miscanthus & Switchgrass \\
\hline N-Fertilizer (kg/ton biomass) & 7.29 & 5 & 5.22 & 0.78 \\
P-Fertilizer (kg/ton biomass) & 6.25 & 2.5 & 5.77 \\
K-Fertilizer (kg/ton biomass) & 3.44 & 10 & 11.11 & - \\
\hline Total fertilizer (kg/ton biomass) & 16.98 & 17.5 & 58.11 \\
\hline Electricity (kWh/ton pellet) & 148.67 & 90.08 & 5.26 \\
\hline
\end{tabular}

$\mathrm{N}$-fertilizer $=$ urea P-fertilizer $=$ TSP $($ Triple Super Phosphate $) ; \mathrm{K}$-fertilizer $=\mathrm{KCl}($ Potassium Chloride $)$.

${ }^{*}$ Table S17 (Supplementary Information) provides a more detailed LCI comparison. 
Table 12

Comparison of the global warming impact of $1 \mathrm{~kg}$ pellet.

\begin{tabular}{|c|c|c|c|c|}
\hline \multirow{2}{*}{ Life cycle stages } & \multicolumn{4}{|c|}{ Global warming impact $(\mathrm{kg} \mathrm{CO}$-eq) } \\
\hline & $\begin{array}{c}\text { This study } \\
\text { (Sorghum) }\end{array}$ & $\begin{array}{l}\text { Lewandowski et al. (1995) } \\
\text { (Miscanthus) }\end{array}$ & $\begin{array}{l}\text { Murphy et al. (2013) } \\
\text { (Miscanthus) }\end{array}$ & $\begin{array}{l}\text { Bergman et al. (2015) } \\
\text { (Switchgrass) }\end{array}$ \\
\hline Biomass production & 0.062 & 0.077 & 0.101 & 0.006 \\
\hline Pellet processing & 0.177 & 0.034 & 0.263 & 0.197 \\
\hline Electricity generation ${ }^{*}$ & 0.050 & 0 & - & - \\
\hline Total & 0.289 & 0.111 & 0.364 & 0.203 \\
\hline
\end{tabular}

*Of the four studies, only this study and Lewandowski et al. (1995) modeled the electricity generation. Both used a carbon-neutral assumption for pellet combustion.

Furthermore, only this study considered emissions from the power plant infrastructure and ash treatment.

considered studies at the level of life cycle stage (biomass production, pellet processing, and electricity generation).

Considering the different modeling choices and assumptions, the results of the various studies listed in Table 12 should be interpreted carefully. In general, it is shown that pellet processing has a higher global warming impact than biomass production, with the exception of the results of Lewandowski et al. (1995) which indicated the opposite. The current study indicated that pellet processing has an impact almost three times higher than that of biomass production, whereas Murphy et al. (2013) reported a slightly smaller difference (almost 2.5 times higher). Surprisingly, Bergman et al. (2015) reported an exceptionally low impact from the stage of biomass production.

As indicated in Section 2.2.1, the sorghum pellet dataset was based on primary data from a field trial, while the data for coal was derived from the ecoinvent dataset "market for lignite RoW". The LCA results showed that for the FU of $1 \mathrm{~kg}$ fuel, the global warming impacts of pellets and coal were 0.239 $\mathrm{kg} \mathrm{CO}_{2}$-eq and $0.0273 \mathrm{~kg} \mathrm{CO}_{2}$-eq, respectively. The global warming impacts of $1 \mathrm{MJ}$ pellets and coal were $0.0146 \mathrm{~kg} \mathrm{CO}_{2}$-eq and $0.0015 \mathrm{~kg} \mathrm{CO}_{2}$-eq, respectively. The impact ratio between pellets and coal was approximately $9: 1$ for both FU (based on $\mathrm{kg}$ of fuel or MJ of energy produced). Furthermore, the global warming impacts of sorghum pellets in the current study are within the range of values reported in other studies on grass pellets. For example, the impact reported for switchgrass was $0.203 \mathrm{~kg} \mathrm{CO}$-eq $/ \mathrm{kg}$ (Bergman et al., 2015), and those for miscanthus were $0.111 \mathrm{~kg} \mathrm{CO}_{2}$-eq $/ \mathrm{kg}$ (Lewandowski et al., 1995 ) and $0.364 \mathrm{~kg} \mathrm{CO}$-eq $/ \mathrm{kg}$ (Murphy et al., 2013). The above analysis confirms that the global impact of pellets is in general higher than that of coal.

The current study indicates that to generate the same amount of electricity, $1.12 \mathrm{~kg}$ of sorghum pellets is required to substitute $1 \mathrm{~kg}$ of coal. Lewandowski et al. (1995) reported higher values, i.e., $1.67 \mathrm{~kg}$ of miscanthus pellets for $1 \mathrm{~kg}$ of coal. This difference might correlate to the type of coals used in their study. For example, Lewandowski et al. (1995) used hard coal with a higher energy content $(29.3 \mathrm{MJ} / \mathrm{kg}, \mathrm{NCV})$, whereas the current study used brown coal of lower energy content (18.3 MJ/kg, NCV). Furthermore, setting brown coal as a reference, the quantity of pellets needed to replace $1 \mathrm{~kg}$ of coal varied among studies. Based on Table 10, the current study indicates that more pellets are needed to replace coal than the amounts reported in the other studies. This is because the energy content of the pellets considered in this study is lower (16.4 $\mathrm{GJ} / \mathrm{ton})$ than those of the pellets considered in the other studies (18-18.6 GJ/ton).

This study explored the impact of the transport of pellets, whereas the transport of coal was not explicitly expressed as it is already aggregated in the coal datasets. Of the three transport systems modeled, land transport (II) (pellet product from factory to ports) contributed the most to the global warming impacts $\left(0.016 \mathrm{~kg} \mathrm{CO}_{2}-\mathrm{eq} / \mathrm{kWh}\right)$, followed by sea transport and land transport (I) (sorghum biomass from fields to pellet factory). Sea transport, involving distances of up to $1,000 \mathrm{~km}$, had a lower impact than land transport (II), involving maximum distances of only $299 \mathrm{~km}$. This demonstrates that the sea transport system is far more efficient than land transport in transporting bulky material over long distances. A similar observation was reported by Wiloso et al. (2019).

\subsection{Study limitations}

The limitations of this study are primarily related to the choices and assumptions made within the LCA modeling. The LCA results are underpinned by at least two main factors, namely the choices of power plant inventories and the assumption of similarity in agricultural conditions (soil properties and climate) between the locations of the field trial (Gresik) and the current scenario study (Flores). Inventory data for the power plant was developed based on the operation of the Suralaya power plant in Banten (Widiyanto et al., 2003). Thus, the material inputs considered were not necessarily exactly representative of the Suralaya power plant in 2017 (Zwebek and Pilidis, 2003). Moreover, this scenario study would have benefitted from the use of a national average of mixed technologies. However, this might not be too problematic as we used the same Suralaya power plant model to compare the three product systems (SFC, CF, and SFP). Thus, the results would be comparable in relative terms.

The inventory for sorghum cultivation in this study came from the agricultural data in Gresik, while the sorghum cultivation scenario was modeled in Flores. In this study, differences in soil fertility and regional climate between the two sites were not considered, which could have resulted in different inventories. Such differences would consequently introduce errors. In practice, this should be adjusted to better reflect fertilizer requirement in Flores, thus improving the quality of the estimate of global warming impacts.

\section{Conclusions and future prospects}

There have been ongoing debates concerning the environmental status of bioenergy systems. Bioenergy is believed to possess significant GHG mitigation potentials, but is simultaneously suspected to increase GHG emissions due to the loss of carbon stocks as a consequence of LUC. Such risk was minimized in this study since the sorghum was grown on parts of under-utilized marginal land, a flat area where sorghum cultivation is possible. Moreover, the revegetation of grassland in Flores with sorghum would likely improve biodiversity and soil properties. This study also considered a comprehensive system boundary encompassing sorghum cultivation, pellet processing, and electricity generation. With this approach, burden-shifting along the life cycle of the product system is minimized. Finally, the sensitivity analysis was carried out to also consider reduced biomass yield, incomplete combustion of biomass, and field emissions from fertilizer application. These three factors (revegetation of marginal land, the comprehensive system boundary, and sensitivity analysis) are believed to have substantially improved the scientific robustness of the following conclusions:

This scenario study modeled the utilization of 100 thousand ha of marginal land in Flores for sorghum biomass cultivation. The following statements answer the five research questions posed in Section 1.6 (Q1-Q5). Based on a biomass yield of 48 ton/ha $y r, 4.8$ million tons of pellets can be produced annually. This amount can in turn generate $8,300 \mathrm{GWh}$ of biomass electricity. For that purpose, 1 ton of coal can be replaced by 1.12 
tons of pellets (Q1). This equivalency is based on maximum potential substitution (100\% displacement), a typical approach in attributional LCA. The calculated FER of the pellets was 5.8, indicating that the production of pellets for fuel is energetically feasible (Q2). As compared to a coal system, the sole combustion of pellets to generate $8,300 \mathrm{GWh}$ of electricity can reduce global warming impacts by 7.9 million tons $\mathrm{CO}_{2}$-eq, which is equivalent to an $85 \%$ reduction in GHG emissions. In co-firing operations, $5 \%$ of the annual electricity produced by all coal-fired power plants in Indonesia, equivalent to $5,300 \mathrm{GWh}$, can be generated via the combustion of 3 million tons of pellets at the plants (Q3). The substitution of coal in this operation reduces global warming impacts by 5.3 million tons $\mathrm{CO}_{2}$-eq (Q4). However, these results would change if emissions from incomplete biomass-combustion $\left(\mathrm{N}_{2} \mathrm{O}\right.$ and $\left.\mathrm{CH}_{4}\right)$ and field application of nitrogenous fertilizers $\left(\mathrm{N}_{2} \mathrm{O}\right)$ were included in the model (Q5). A sensitivity analysis of the above factors, including reduced biomass yield and biomass loss, showed that the projected GHG savings could be reduced from the initial value of $85 \%$ to as low as $70 \%$.

This study found that sorghum cultivation and pellet processing were the hotspots of the electricity generated from sorghum pellets. This is in line with the results of similar studies based on different grass pellets, namely switchgrass and miscanthus. Further investigations showed that fertilizer application in sorghum cultivation and electricity requirements in pellet processing were the most responsible factors.

Sorghum pellets have a relatively high ash content, which may make combustion chambers prone to technical problems such as slagging or fouling. In comparison with coal, the ash content of pellets (7\%) is actually acceptable for application in both PC and CFB technologies. However, the presence of inorganic elements such as $\mathrm{N}, \mathrm{K}$, and $\mathrm{Cl}$ may pose problems, especially if applied in a PC power plant converted from an oil-fired boiler system. Such power plants require pellets with ash content of less than $1 \%$ (Stromberg, 2006). In this regard, further research toward reducing the ash content of pellets is recommended, for example via washing the biomass with water prior to pellet processing, or mixing of the sorghum pellets with other pellets of lower ash content.

It is concluded that the production of sorghum pellets in Flores and its utilization for electricity generation can significantly reduce the reliance on fossil fuels and contribute to climate change mitigation. Sensitivity analysis shows that 2.4 million tons of pellets, based on 24 ton sorghum/ha.yr, can generate $4,150 \mathrm{GWh}$ electricity. In contrast to the reference scenario, the reduced biomass amount can supply only $78 \%$ of existing coal-fired power plants capacity in Indonesia for 5\% co-firing operation.

In addition to the above findings; however, other impact categories and factors outside the system boundary might contribute to these aspects as well. Hence, a more complete impact category coverage and a consequential approach considering market mechanism may be needed for more comprehensive examination. Further studies considering actual carbon balance (uptake and release) instead of a carbon-neutral assumption is also recommended. The results of this scenario study can also assist the government in exploring the potential utilization of marginal land for bioenergy development, both in Indonesia and beyond.

\section{Acknowledgments}

We would like to thank Patrik J.G. Henriksson of the Stockholm Resilience Centre, Stockholm University and WorldFish for his valuable input and suggestions on an earlier version of the manuscript. This work was supported by SATREPS-JICA, the project for producing biomass energy and material through the revegetation of Alang-alang (Imperata cylindrica) fields, a collaborative project between the Indonesian Institute of Sciences (LIPI), Indonesia, and Kyoto University, Japan.

\section{References}

[1] Aho, M., Envall, T., Kauppinen, J., 2013. Corrosivity of flue gases during co-firing Chinese biomass with coal at fluidised bed conditions. Fuel Process. Technol. 105, 82-88.

[2] Ameen, A., Yang, X., Chen, F., Tang, C., Du, F., Fahad, S., Xie, G.H., 2017. Biomass yield and nutrient uptake of energy sorghum in response to nitrogen fertilizer rate on marginal land in a semi-arid region. Bioenergy Res. 10(2), 363-376.
[3] Ansermet, J.P., Brechet, S.D., 2019. Principles of Thermodynamics. Cambridge University Press.

[4] Atilgan, B., Azapagic, A., 2015. Life cycle environmental impacts of electricity from fossil fuels in Turkey. J. Clean. Prod. 106, 555-564.

[5] Baker, J.M., Ochsner, T.E., Venterea, R.T., Griffis, T.J., 2007. Tillage and soil carbon sequestration-what do we really know?. Agric. Ecosyst. Environ. 118(1-4), 1-5.

[6] Bappenas, 2016. Laporan Akhir: Kajian Ketercapaian Target DMO Batubara Sebesar 60\% Produksi Nasional pada Tahun 2019.

[7] Bappenas, 2019. Low Carbon Development: A Paradigm Shift Towards a Green Economy in Indonesia.

[8] Barros, M.V., Salvador, R., Piekarski, C.M., de Francisco, A.C., Freire, F.M.C.S., 2019. Life cycle assessment of electricity generation: a review of the characteristics of existing literature. Int. J, Life Cycle Assess. 25(1), 36-54

[9] Beér, J.M., 2007. High efficiency electric power generation: the environmental role. Prog. Energy Combust. Sci. 33(2), 107-134.

[10] Bergman, R.D., Reed, D.L., Taylor, A.M., Harper, D.P., Hodges, D.G., 2015. Cradle-to-gate life cycle assessment of switchgrass fuel pellets manufactured in the Southeastern United States1. Wood Fiber Sci. 47(2), 147-159

[11] Bhatt, M.S., 2006. Effect of ash in coal on the performance of coal fired thermal power plants. Part II: capacity and secondary energy effects. Energy Sources Part A. 28(1), 43-58

[12] Boylan, D.M., 1996. Southern company tests of wood/coal cofiring in pulverized coal units. Biomass Bioenergy. 10(2-3), 139-147.

[13] BPDASHL Benain Noelmina, 2018. Peta Lahan Kritis Wilayah Kerja BPDAS Benain Noelmina. East Nusa Tenggara.

[14] BPS NTT, 2020. Nusa Tenggara Timur Province in Figures 2019. BPS NTT Province. Kupang.

[15] Brentrup, F., Küsters, J., Lammel, J., Kuhlmann, H., 2000. Methods to estimate on-field nitrogen emissions from crop production as an input to LCA studies in the agricultural sector. Int. J. Life Cycle Assess. 5(6), 349

[16] Cavigelli, M.A., Grosso, S.J., Liebig, M.A., Snyder, C.S., Fixen, P.E., Venterea, R.T., Leytem, A.B., McLain, J.E., Watts, D.B., 2012. US agricultural nitrous oxide emissions: context, status, and trends. Front. Ecol. Environ. 10(10), 537-546.

[17] Chen, R., Lin, X., Wang, Y., Hu, J., 2011. Mitigating methane emissions from irrigated paddy fields by application of aerobically composted livestock manures in eastern China. Soil Use Manage. 27(1), 103-109

[18] Daystar, J., Reeb, C., Gonzalez, R., Venditti, R., Kelley, S.S., 2015. Environmental life cycle impacts of cellulosic ethanol in the Southern U.S. produced from loblolly pine, eucalyptus, unmanaged hardwoods, forest residues, and switchgrass using a thermochemical conversion pathway. Fuel Process. Technol. 138, 164-174

[19] Demirbas, A., 2004. Combustion characteristics of different biomass fuels. Prog. Energy Combust. Sci. 30(2), 219-230.

[20] Döll, P., Petschel-Held, G., Leemans, R., 2008. Scale issues in scenario development. Environ. Futur. Pract. Environ. Scenar. Anal. $1-16$.

[21] Dunaievska, N., Chernyavskiy, M., Shchudlo, T., 2016. Cocombustion of solid biomass in pulverized anthracite-coal firing boilers. Ukr. Food J. 5(4), 748-764.

[22] Elduque, A., Javierre, C., Elduque, D., Fernández, Á., 2015. LCI databases sensitivity analysis of the environmental impact of the injection molding process. Sustainability. 7(4), 3792-3800.

[23] Eurostat, 2019. Energy statistics-an overview. Eurostat Official Website.

[24] Fadli, M., Kamal, D.M., Adhi, P.M., 2019. SWOT analysis for direct coal co-firing with waste pellets on CFBC type boilers. J. PoliTeknologi. 18, 271-280.

[25] Frischknecht, R., Jungbluth, N., Althaus, H.J., Bauer, C., Doka, G., Dones, R., Hischier, R., Hellweg, S., Humbert, S., Köllner, T. Loerincik, Y., 2007. Implementation of Life Cycle Impact Assessment Methods.

[26] García, R., Gil, M.V., Rubiera, F., Pevida, C., 2019. Pelletization of wood and alternative residual biomass blends for producing industrial quality pellets. Fuel. 251, 739-753. 
[27] Gelfand, I., Sahajpal, R., Zhang, X., Izaurralde, R.C., Gross, K.L., Robertson, G.P., 2013. Sustainable bioenergy production from marginal lands in the US Midwest. Nature. 493(7433), 514-517.

[28] Goglio, P., Smith, W.N., Grant, B.B., Desjardins, R.L., McConkey, B.G., Campbell, C.A., Nemecek, T., 2015. Accounting for soil carbon changes in agricultural life cycle assessment (LCA): a review. J. Clean. Prod. 104, 23-39

[29] Guinée, J.B., Gorrée, M., Heijungs, R., Huppes, G., Kleijn, R., Koning, A., de, Oers, L. van, Sleeswijk, A.W., Suh, S., Udo de Haes, H.A., Bruijn, H., de Duin, R., van Huijbregts, M.A.J., 2002. Handbook on life cycle assessment: Operational guide to the ISO standards. Springer Science and Business Media. 7.

[30] Head, M., Bernier, P., Levasseur, A., Beauregard, R., Margni, M., 2019. Forestry carbon budget models to improve biogenic carbon accounting in life cycle assessment. J. Cleaner Prod. 213, 289-299.

[31] Hidayat, A., 2009. Sumberdaya lahan Indonesia: potensi, permasalahan, dan strategi pemanfaatan. J. Sumberdaya Lahan. 3(2), 107-117.

[32] Husaini, A., 2020. PLTU Indramayu ujicoba gunakan wood pellet untuk bahan bakar pembangkit.

[33] IEA, 2019a. CO2 emissions from fuel combustion: overview.

[34] IEA, 2019b. Coal Information: overview.

[35] IEA, 2019c. Coal Information 2019 Edition.

[36] IEA, 2017. Technology Roadmap-Delivering Sustainable Bioenergy. International Energy Agency.

[37] IEA, 2004. Energy Statistics Manual, Energy Statistics Manual.

[38] IEA Clean Coal Centre, 2016. Potential water sources for coal-fired power plants.

[39] IPCC, 2006a. IPCC Guidelines for National Greenhouse Gas Inventories.

[40] IPCC, 2006b. IPCC- $\mathrm{N}_{2} \mathrm{O}$ Emissions from managed Soils and $\mathrm{CO}_{2}$ Emissions From, Agriculture.

[41] ISO 14040, 2006. Environmental management-Life cycle assessmentPrinciples and framework.

[42] ISO 14044, 2006. Environmental management-Life cycle assessmentRequirements and guidelines.

[43] Jannasch, R., Quan, Y., Samson, R., 2001. A process and energy analysis of pelletizing switchgrass. Prepared REAP Can.Natural Resour. Can.

[44] Jungbluth, N., Meili, C., Wenzel, P., 2018. Life cycle inventories of oil refinery processing and products. ESU-services Ltd. BFE, BAFU, ErdölVereinigung.

[45] Khaerunisa, H., Huda, M., Damayanti, R., Antono, H.T., Komarudin Yaskuri, D., Lutfi, M., Suryati, E., Alimano, M., Nurhadi, H., Sibarani, L., Hayati, I., Mujahidin, S., 2009. Study of $\mathrm{CO}_{2}$ emissions from coal combustion in Indonesia. Bandung.

[46] Khoshnevisan, B., Rafiee, S., Omid, M., Yousefi, M., Movahedi, M., 2013. Modeling of energy consumption and GHG (greenhouse gas) emissions in wheat production in Esfahan province of Iran using artificial neural networks. Energy. 52, 333-338.

[47] Kim, S.Y., Pramanik, P., Gutierrez, J., Hwang, H.Y., Kim, P.J., 2014. Comparison of methane emission characteristics in air-dried and composted cattle manure amended paddy soil during rice cultivation. Agric. Ecosyst. Environ. 197, 60-67.

[48] Kurniawan, H., Yuniati, D., 2015. Carbon sink potency in three types of savannah in Nusa Tenggara Timur (in Indonesian). J. Penelitian Kehutanan Wallacea. 4(1), 51-62.

[49] Lee, J.S., 2015. Calorific value of wood pellets. The University of British Columbia.

[50] Lewandowski, I., Kicherer, A., Vonier, P., 1995. $\mathrm{CO}_{2}$-balance for the cultivation combustion of Miscanthus. Biomass Bioenergy. 8(2), 81-90,

[51] Livingston, W.R., 2016. The status of large scale biomass firing. The milling and combustion of biomass materials in large pulverised coal boilers. IEA Bioenergy: Task 32: Biomass Combustion and co-firing.

[52] Lockwood, T., 2013. Techno-economic analysis of PC versus CFB combustion technology. IEA Clean Coal Centre, Report CCC/226, London, UK.

[53] Matheus, R., Basri, M., Rompon, M.S., Neonufa, N., 2017. Strategi pengelolaan pertanian lahan kering dalam meningkatkan ketahanan pangan di Nusa Tenggara Timur. Partner. 22(2), 529-541.

[54] MEMR, 2018a. Pengesahan rencana usaha penyediaan tenaga listrik PT PLN 2018-2027. Ministry of Energy and Mineral Resources. Indonesia.
[55] MEMR, 2018b. Statistik Ketenagalistrikan T.A. 2018. Ministry of Energy and Mineral Resources. Indonesia.

[56] MEMR, 2019. Outlook Energy Indonesia 2019. Ministry of Energy and Mineral Resources. Indonesia.

[57] MEMR, 2020. Dukung target bauran EBT, PLN lakukan uji coba metode co-firing PLTU. Ministry of Energy and Mineral Resources of the Republic of Indonesia.

[58] Miller, B.G., 2004. Coal Energy Systems. Elsevier Academic Press, Cambridge.

[59] MoEF, 2018. Keputusan Menteri Lingkungan Hidup dan Kehutanan nomor: SK. 306/MENLHK/PDASHL/DAS.0/7/2018. Tentang Penetapan Lahan Kritis Nasional. Ministry of Environment and Forestry. Indonesia.

[60] Morrison, B., Golden, J.S., 2017. Life cycle assessment of co-firing coal and wood pellets in the Southeastern United States. J. Clean. Prod. 150, 188-196.

[61] Mostafa, M.E., Hu, S., Wang, Y., Su, S., Hu, X., Elsayed, S.A., Xiang, J., 2019. The significance of pelletization operating conditions: an analysis of physical and mechanical characteristics as well as energy consumption of biomass pellets. Renew. Sust. Energy Rev. 105, 332348

[62] Mulyani, A., Priyono, A. Agus, F., 2013. Semiarid soils of eastern Indonesia: soil classification and Land Uses, in: Shahid, S.A., et al. (Eds.), Developments in Soil Classification, Land Use Planning and Policy Implications: Innovative Thinking of Soil Inventory for Land Use Planning and Management of Land Resources. Springer Science and Business Media Dordrecht. pp. 449-466.

[63] Murphy, F., Devlin, G., McDonnell, K., 2013. Miscanthus production and processing in Ireland: an analysis of energy requirements and environmental impacts. Renew. Sust. Energy Rev. 23, 412-420.

[64] NCBI, 2014. PubChem Database. Deltamethrin, CID $=40585$.

[65] NCBI, 2004. PubChem Database. Carbofuran, CID $=2566$.

[66] Nian, V., 2016. The carbon neutrality of electricity generation from woody biomass and coal, a critical comparative evaluation. Appl. Energy. 179, 1069-1080.

[67] Oertel, C., Matschullat, J., Zurba, K., Zimmermann, F., Erasmi, S., 2016. Greenhouse gas emissions from soils-a review. Geochemistry. 76(3), 327-352

[68] PLN, 2018. Statistik PLN 2017. Sekretariat Perusahaan PT PLN (Persero), Jakarta.

[69] PLN, 2019. Buku Statistik PLN 2018. Sekretariat Perusahaan PT PLN (Persero), Jakarta.

[70] Pradhan, A., Shrestha, D.S., McAloon, A., Yee, W., Haas, M., Duffield, J.A., Shapouri, H., 2010. Energy life-cycle assessment of soybean biodiesel. Biofuel Lifecycle Issues Res. 121.

[71] Qu, H., Liu, X.B., Dong, C.F., Lu, X.Y., Shen, Y.X., 2014. Field performance and nutritive value of sweet sorghum in eastern China Field Crops Res. 157, 84-88.

[72] Rajaeifar, M.A., Ghobadian, B., Heidari, M.D., Fayyazi, E., 2013 Energy consumption and greenhouse gas emissions of biodiesel production from rapeseed in Iran. J. Renew. Sust. Energy. 5(6), 1-14

[73] Reuters, 2020. Indonesia plans to replace old coal power plants with renewable plants: minister.

[74] Robertson, G.P., Hamilton, S.K., Barham, B.L., Dale, B.E., Izaurralde, R.C., Jackson, R.D., Landis, D.A., Swinton, S.M., Thelen, K.D., Tiedje, J.M., 2017. Cellulosic biofuel contributions to a sustainable energy future: choices and outcomes. Science. 356(6345).

[75] Russell-Smith, J., Djoeroemana, S., Maan, J., Pandanga, P., 2007. Rural livelihoods and burning practices in Savanna landscapes of Nusa Tenggara Timur, Eastern Indonesia. Hum. Ecol. 35(3), 345-359.

[76] Sainju, U.M., Singh, H.P., Singh, B.P., 2015. Cover crop effects on soil carbon and nitrogen under bioenergy sorghum crops. J. Soil Water Conserv. 70(6), 410-417.

[77] Sajdak, M., Kmieć, M., Micek, B., Hrabak, J., 2019. Determination of the optimal ratio of coal to biomass in the co-firing process: feed mixture properties. Int. J. Environ. Sci. Technol. 16(7), 2989-3000.

[78] Schakel, W., Meerman, H., Talaei, A., Ramírez, A., Faaij, A., 2014. Comparative life cycle assessment of biomass co-firing plants with carbon capture and storage. Appl. Energy. 131, 441-467. 
[79] Serra, P., Colauzzi, M., Amaducci, S., 2017. Biomass sorghum production risk assessment analysis: a case study on electricity production in the Po Valley. Biomass Bioenergy. 96, 75-86.

[80] Simons, A., 2016. Road transport: new life cycle inventories for fossilfuelled passenger cars and non-exhaust emissions in ecoinvent v3. Int. J. Life Cycle Assess. 21(9), 1299-1313.

[81] Sondreal, E.A., Benson, S.A., Hurley, J.P., Mann, M.D., Pavlish, J.H., Swanson, M.L., Weber, G.F., Zygarlicke, C.J., 2001. Review of advances in combustion technology and biomass cofiring. Fuel Process. Technol. 71(1-3), 7-38

[82] Stromberg, B., 2006. Fuel Handbook. Stockholm (Sweden).

[83] Suh, S., Weidema, B., Schmidt, J.H., Heijungs, R., 2010. Generalized make and use framework for allocation in life cycle assessment. J. Ind. Ecol. 14(2), 335-353.

[84] Tang, C., Li, S., Li, M., Xie, G.H., 2018. Bioethanol potential of energy sorghum grown on marginal and arable lands. Front. Plant Sci. 9, 440.

[85] U.S. Energy Information Administration, 2019. September 2019 Monthly Energy Review, U.S. Energy Information Administration.

[86] van Amstel, A.R., Swart, R.J., 1994. Methane and nitrous oxide emissions: an introduction. Fert. Res. 37(3), 213-225.

[87] Wahyuni, N., 2014. Working time allocation and income of cattle farmers at Megang Sakti Subdistrict Musi Rawas Regency. Societa: Jurnal IlmuIlmu Agribisnis.

[88] Weidema, B., 2000. Avoiding co-product allocation in life-cycle assessment. J. Ind. Ecol. 4(3), 11-33.

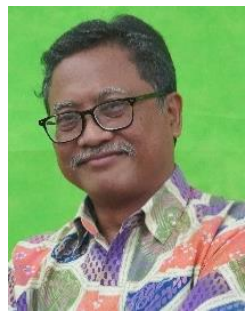

Dr. Edi Iswanto Wiloso is the head of LCA research group at the Research Center for Science, Technology and Innovation Policy and Management, Indonesian Institute of Sciences. Edi received his $\mathrm{PhD}$ from the Institute of Environmental Sciences, Leiden University, The Netherlands. Currently, he serves as the chief editor at the Indonesian Journal of Life Cycle Assessment and Sustainability. Edi is also a co-founder of the Indonesian LCA Network, for which he served as the $1^{\text {st }}$ chairman between 2015 and 2018. His research interest is on environmental sustainability of products and life cycle assessment.

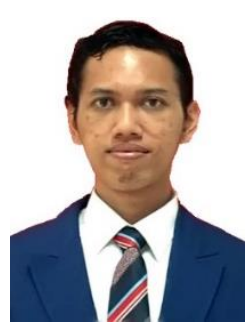

Arief Ameir Rahman Setiawan is a researcher at the Research Center for Science, Technology and Innovation Policy and Management, Indonesian Institute of Sciences. He received a master degree from the Graduate School of Industrial and Management System Engineering, Waseda University. He serves as the managing editor of the Indonesian Journal of Life Cycle Assessment and Sustainability. His research interest includes life cycle assessment in particular related to green supply chain and sustainable technology development.

[89] Weidema, B.P., Bauer, C., Hischier, R., Mutel, C., Nemecek, T., Reinhard, J., Vadenbo, C.O., Wenet, G., 2013. Data quality guideline for the ecoinvent database version 3. Ecoinvent Report 1 (v3). Swiss Cent. Life Cycle Invent. 3.

[90] Wernet, G., Bauer, C., Steubing, B., Reinhard, J., Moreno-Ruiz, E. Weidema, B., 2016. The ecoinvent database version 3 (part I): overview and methodology. Int. J. Life Cycle Assess. 21(9), 1218 1230.

[91] Widiyanto, A., Kato, S., Maruyama, N., 2003. Environmental impact analysis of indonesian electric generation system (development of a life cycle inventory of indonesian electricity). JSME Int. J., Ser. B. 46(4), 650-659.

[92] Wiloso, E.I., Heijungs, R., Huppes, G., Fang, K., 2016. Effect of biogenic carbon inventory on the LCA of bioenergy: challenges to the neutrality assumption. J. Clean. Prod. 125, 78-85.

[93] Wiloso, E.I., Sinke, P., Muryanto, Setiawan, A.A.R., Sari, A.A., Waluyo, J., Putri, A.M.H., Guinée, J., 2019. Hotspot identification in the Indonesian tempeh supply chain using life cycle assessment. Int. J. Life Cycle Assess. 24(11), 1948-1961.

[94] Yang, B., Wei, Y.M., Hou, Y., Li, H., Wang, P., 2019. Life cycle environmental impact assessment of fuel mix-based biomass co-firing plants with $\mathrm{CO}_{2}$ capture and storage. Appl. Energy. 252, 113483.

[95] Zaimes G., Borkowski, M., Khanna, V., 2013. Life-Cycle Environmental Impacts of Biofuels and Co-products, in: Gupta, V.K., Tuohy, M.G. (Eds.), Biofuel Technologies: Recent Developments. Springer Heidelberg New York Dordrecht London. pp.471-499.

[96] Zwebek, A., Pilidis, P., 2003. Degradation effects on combined cycle power plant performance-Part II: steam turbine cycle component degradation effects. J. Eng. Gas Turbines Power. 125(3), 658-663.

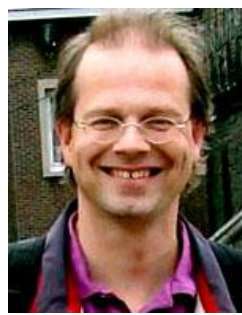

Dr. Reinout Heijungs is an Associate Professor at the School of Business and Economics of Vrije Universiteit Amsterdam, The Netherlands. He has been active in quantitative sustainability analysis since 1991, and takes a special interest in mathematical and statistical aspects.

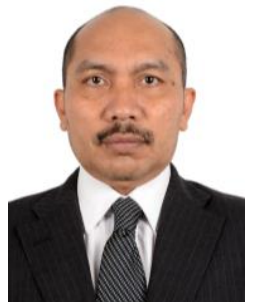

Indonesia.
Dr. I Made Sudiana is a Professor in microbial ecology at the Research Center for Biology, Indonesian Institute of Sciences. He has been working on the revegetation of deteriorated ecosystems and marginal lands, introduction of microbial ecology tools to assess the microbial diversity status of soil ecosystem, and development of microbial technologies to increase soil productivity and sustainability. Sudiana is the secretary of the Research Professor Association in 


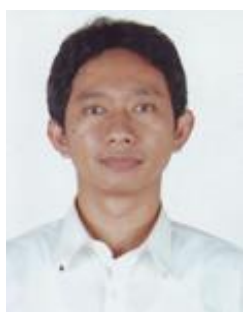

Dr. Satya Nugroho is a plant molecular biologist and breeder at the Research Center for Biotechnology, Indonesian Institute of Sciences. He is involved in research and development in crop biotechtechnology and especially rice in Indonesia. He received his $\mathrm{PhD}$ in Biochemistry and Molecular Biology from the Research School for Biological Sciences at the Australian National University. Currently, he also serves as the head of the Plant Group of the Technical Team for Environmental Biosafety of GM Crops, and has been involved in the development of the current regulations and guidance on the release of GM Crops in Indonesia.

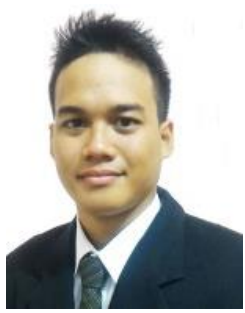

Adisa Ramadhan Wiloso holds a bachelor in mechanical and biosystem engineering from the Bogor Agricultural University, Indonesia. He is currently pursuing his master degree at the Pamulang University. His research interests include life cycle assessment and bioenergy.

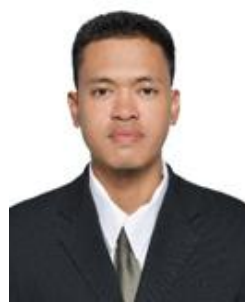

Muryanto is a researcher at the Research Centre for Chemistry, Indonesia Institute of Sciences. He received his master degree in chemical engineering from the University of Indonesia. His research fields are bioenergy and the environment. Currently, he is active in research on bioethanol and biorefinery from lignocellulosic biomass, wastewater treatment, and life cycle assessment on several chemical products.

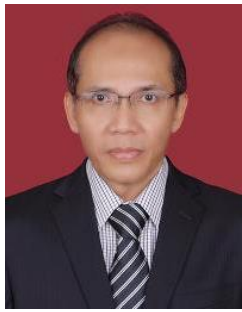

Dr. Subyakto is a Research Professor at the Research Center for Biomaterials, Indonesian Institute of Sciences. He received his doctoral degree in Agriculture Science from the Kyoto University, Japan. His research interests include development of biocomposites from wood and natural fibers and their properties enhancement.

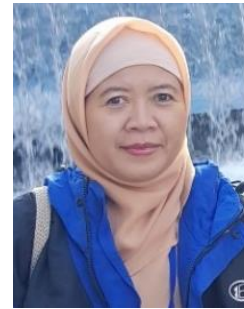

Dr. Reni Lestari is a senior researcher at the Research Center for Plant Conservation and Botanic Gardens, Indonesian Institute of Sciences. She obtained her bachelor degree in agriculture at the IPB University, Indonesia and master degree in botany at the James Cook University of Northern Queensland, Australia. She received her $\mathrm{PhD}$ from the Faculty of Agriculture and Horticulture of Humboldt University of Berlin, Germany. She has been collaborating with the Botanic Garden Conservation International Congress (Oxford, UK) and the University of Hohenheim (Stuttgart, Germany). Her research interests include botany, plant conservation, horticulture and agriculture

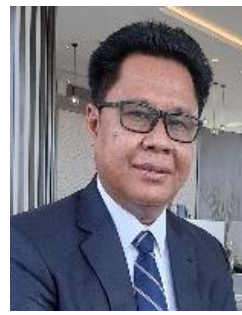

Dr. Dede Hermawan is an Associate Professor at the Forest Product Technology Department, Faculty of Forestry and Environment, IPB University (Bogor, Indonesia). His research interests include the utilization of biomass as raw materials for biocomposites and bioenergy.

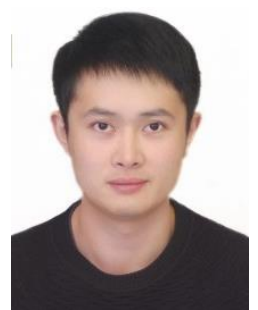

Dr. Kai Fang is a tenured Associate Professor in environmental management at the Zhejiang University. He received his $\mathrm{PhD}$ from the Institute of Environmental Sciences (CML), Leiden University. His research interests include environmental footprints, integrated sustainability assessment and climate change economics. He is now a member of the editorial board of Journal of Cleaner Production and Regional Sustainability.

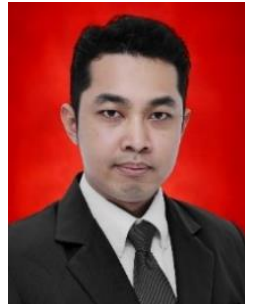

Dr. Hafiizh Prasetia is a research associate at the Research Centre for Chemistry, Indonesia Institute of Sciences. He received his $\mathrm{PhD}$ from the Brawijaya University, Malang, Indonesia. $\mathrm{He}$ serves as the Section Editor at the Indonesian Journal of Life Cycle Assessment and Sustainability. His research interests include Analytical and Environment Chemistry. 


\section{Supplementary Information}

Table S1.

Marginal land distribution in Indonesia*.

\begin{tabular}{|c|c|c|}
\hline No. & Province & Critical land area (ha) \\
\hline 1 & Nanggroe Aceh Darusalam & 316,637 \\
\hline 2 & Sumatera Utara & $1,338,810$ \\
\hline 3 & Sumatera Barat & 651,970 \\
\hline 4 & Riau & 710,873 \\
\hline 5 & Kepulauan Riau & 8,230 \\
\hline 6 & Jambi & 213,985 \\
\hline 7 & Bengkulu & 148,887 \\
\hline 8 & Sumatera Selatan & 733,756 \\
\hline 9 & Bangka Belitung & 20,687 \\
\hline 10 & Lampung & 403,910 \\
\hline 11 & Banten & 330,408 \\
\hline 12 & DKI Jakarta & - \\
\hline 13 & Jawa Barat & 911,192 \\
\hline 14 & Jawa Tengah & 375,733 \\
\hline 15 & DI. Yongyakarta & 79,123 \\
\hline 16 & Jawa Timur & 432,225 \\
\hline 17 & Bali & 46,895 \\
\hline 18 & Nusa Tenggara Barat & 65,799 \\
\hline 19 & Nusa Tenggara Timur & 840,914 \\
\hline 20 & Kalimantan Barat & $1,015,631$ \\
\hline 21 & Kalimantan Tengah & 861,240 \\
\hline 22 & Kalimantan Selatan & 511,594 \\
\hline 23 & Kalimantan Timur & 275,272 \\
\hline 24 & Kalimantan Utara & 199,734 \\
\hline 25 & Sulawesi Utara & 289,782 \\
\hline 26 & Gorontalo & 332,298 \\
\hline 27 & Sulawesi Tengah & 264,874 \\
\hline 28 & Sulawesi Barat & 88,421 \\
\hline 29 & Sulawesi Selatan & 449,606 \\
\hline 30 & Sulawesi Tenggara & 424,655 \\
\hline 31 & Maluku & 299,607 \\
\hline 32 & Maluku Utara & 387,889 \\
\hline 33 & Papua Barat & 437,288 \\
\hline 34 & Papua & 538,523 \\
\hline Total & & 14.006 .450 \\
\hline
\end{tabular}

* Source: Ministry of Environment and Forestry of Indonesia

(Report on national critical land area per province in 2018)

Table S2.

Marginal land distribution in Flores Island*.

\begin{tabular}{|c|c|c|c|c|c|c|}
\hline \multirow{2}{*}{ Region } & \multicolumn{6}{|c|}{ Level of marginality } \\
\hline & Non marginal (a) & Potentially marginal (b) & Rather marginal (c) & Marginal $^{\mathbf{a}}$ (d) & Very marginal (e) & Marginal+ very marginal $(d+e)$ \\
\hline Alor & 8,329 & 22,534 & 236,731 & 28,800 & 2,657 & 31,458 \\
\hline Ende & 6,129 & 26,045 & 157,299 & 23,837 & - & 23,837 \\
\hline Flores Timur & 4,105 & 20,644 & 114,966 & 37,677 & 1,236 & 38,913 \\
\hline Lembata & 7,316 & 20,288 & 72,082 & 28,929 & 926 & 29,855 \\
\hline Manggarai & - & 3,372 & 77,998 & 55,561 & 34 & 55,595 \\
\hline Manggarai Barat & 5,513 & 23,668 & 230,415 & 59,555 & 1,784 & 61,340 \\
\hline Manggarai Timur & 6,499 & 13,534 & 146,759 & 78,413 & 497 & 78,909 \\
\hline Nagekeo & 21,155 & 66,853 & 42,581 & 16,484 & - & 16,484 \\
\hline Ngada & 6,208 & 32,169 & 89,481 & 43,675 & 1,276 & 44,951 \\
\hline Sikka & 6,382 & 36,853 & 87,554 & 40,376 & 186 & 40,562 \\
\hline Total & 71,635 & 265,960 & $1,255,866$ & 413,307 & 8,596 & 421,904 \\
\hline
\end{tabular}

* Source: BPDASHL Benain Noelmina (2018)

${ }^{a}$ The term critical land is equivalent to marginal land (as used throughout this section of the paper). 
Table S3.

Power plant technology commonly used in Indonesia*.

\begin{tabular}{|c|c|c|c|c|}
\hline Power plant & Location & Year of operation & Installed capacity & Type $^{\text {b }}$ \\
\hline Ombilin & West Sumatera & 1996 & $2 \times 100 \mathrm{MW}$ & $\mathrm{PC}$ \\
\hline Bukit Asam & South Sumatera & $\begin{array}{l}1987 \text { (unit } 1 \& \text { 2) } \\
1994 \text { (unit 3) } \\
1995 \text { (unit 4) }\end{array}$ & 4x65 MW & $\mathrm{PC}$ \\
\hline Paiton PLN & East Java & $\begin{array}{l}1993 \text { (unit 2) } \\
1994 \text { (unit 1) }\end{array}$ & $2 \times 400 \mathrm{MW}$ & $\mathrm{PC}$ \\
\hline Asam-Asam & South Kalimantan & 2000 & 2x65 MW & $\mathrm{PC}$ \\
\hline Tarahan $3 \& 4$ & Lampung & 2007 & $2 \times 100 \mathrm{MW}$ & CFB \\
\hline Tanjung Jati B & Central Java & 2006 & $2 \times 660 \mathrm{MW}$ & $\mathrm{PC}$ \\
\hline Labuhan Angin & North Sumatera & $\begin{array}{l}2008 \text { (unit 2) } \\
2009 \text { (unit 1) }\end{array}$ & $2 \times 115 \mathrm{MW}$ & CFB \\
\hline Suralaya $^{a} 1-8$ & Banten & $\begin{array}{l}1984 \text { (unit } 1 \& \text { 2) } \\
1989 \text { (unit } 3 \& \text { 4) } \\
1997 \text { (unit 5, 6, \& 7) } \\
2011 \text { (unit 8) }\end{array}$ & $\begin{array}{l}400 \mathrm{MW} \text { (unit } 1-4 \text { ) } \\
600 \mathrm{MW} \text { (unit } 5-7 \text { ) } \\
625 \mathrm{MW} \text { (unit 8) }\end{array}$ & $\mathrm{PC}$ \\
\hline
\end{tabular}

* Source: Khaerunisa et al. (2009)

a Source: PTIP (2018)

${ }^{\mathrm{b}} \mathrm{PC}=$ pulverized coal; $\mathrm{CFB}=$ circulating fluidized bed

Table S4.

Suitability of fuel characteristics and power plant technologies*.

\begin{tabular}{|c|c|c|}
\hline \multirow{2}{*}{ Fuel parameter } & \multicolumn{2}{|c|}{ Standard characteristic } \\
\hline & $\mathbf{P C}$ & CFB \\
\hline Calorific value & Medium to high $>15 \mathrm{MJ} / \mathrm{kg}$ & Wide range from about $5 \mathrm{MJ} / \mathrm{kg}$ to dry fuels \\
\hline Moisture content & $<15 \%$ moisture content. Dry fuel necessary for quick ignition. & $\begin{array}{l}\text { High moisture contents may be acceptable. Range of 5-60\%, depending on } \\
\text { design }\end{array}$ \\
\hline Ash content & $\begin{array}{l}<1 \% \text { for converted oil-fired boilers. Other pulverized fuel boilers more } \\
\text { insensitive. }\end{array}$ & Insensitive to ash with high melting point. Low content if ash is difficult. \\
\hline Alkali content & $\begin{array}{l}\text { High content generally causes deposits. High combustion temperature } \\
\text { causes alkali in the gas phase/fly ash. }\end{array}$ & High content may lead to the risk of bed sintering and risk of deposits \\
\hline Chlorine and sulphur content & $\begin{array}{l}\text { Of general importance to high and low temperature corrosion and to the } \\
\text { formation of deposits }\end{array}$ & $\begin{array}{l}\text { Of general importance to high and low temperature corrosion and to the } \\
\text { formation of deposits. Scope for effective sulphur capture in the bed. }\end{array}$ \\
\hline
\end{tabular}

* Source: Stromberg (2006)

$\mathrm{PC}=$ pulverized coal $; \mathrm{CFB}=$ circulating fluidized bed .

Table S5.

The application of biomass co-firing in various power plant technologies*.

\begin{tabular}{|c|c|c|c|}
\hline Study & Type of biomass & Form of biomass & Power plant type \\
\hline Tabata et al. (2011) & Wood & Briquettes & $\mathrm{PC}$ \\
\hline Schakel et al. (2014) & Wood \& straw & Pellets & PC \& IGCC \\
\hline Morrison and Golden (2017) & Wood & Pellets & $\mathrm{PC}$ \\
\hline Shafie et al. (2013) & Straw & Straw (without forming/shaping treatment) & $\mathrm{PC}$ \\
\hline Woytiuk et al. (2017) & Willow & Torrefied pellets & PC \& CFBG \\
\hline Wu et al. (2016) & Corn stalk & Stalk (without forming/shaping treatment) & PC \\
\hline Sathitruangsak and Madhiyanon (2017) & Rice husk & Rice husk (without forming/shaping treatment) & CFB \\
\hline Gungor (2013) & Rice husk and wood chips & Rice husk (without forming/shaping treatment) and chips & CFB \\
\hline Aho et al. (2013) & Wheat straw, corn straw and saw dust & Without forming/shaping treatment & CFB \\
\hline
\end{tabular}

* Source: primary data

PC=pulverized coal; IGCC=integrated gasification combined cycle; $\mathrm{CFB}=$ circulating fluidized bed; $\mathrm{CFBG}=$ circulating fluidized bed gasifier.

Please cite this article as: Wiloso E.I., Setiawan A.A.R., Prasetia H., Muryanto, Wiloso A.R., Subyakto, Sudiana I.M., Lestari R., Nugroho S., Hermawan D., Fang K., Heijungs R. Production of sorghum pellets for electricity generation in Indonesia: A life cycle assessment. Biofuel Research Journal 27 (2020) 1178 1194. DOI: 10.18331/BRJ2020.7.3.2 
Table S6.

Emission factors used in this study.

\begin{tabular}{lcccc}
\hline & \multicolumn{3}{c}{ Emission factor $(\mathbf{k g} / \mathbf{M J})^{\text {a }}$} & \\
\cline { 2 - 4 } & $\mathbf{C O}_{2}$ & $\mathbf{C H}_{4}$ & $\mathbf{N}_{2} \mathbf{O}$ & Activity \\
\hline Diesel & $7.48 \mathrm{E}-2$ & $10 \mathrm{E}-6$ & $2 \mathrm{E}-6$ & Sorghum cultivation and pellet processing \\
Brown coal & $1.15 \mathrm{E}-1$ & $3 \mathrm{E}-6$ & $5 \mathrm{E}-6$ & Electricity generation (SFC and CF) \\
Pellet ${ }^{\text {b }}$ & 0 & $1 \mathrm{E}-4$ & $1.5 \mathrm{E}-5$ & Electricity generation (CF and SFP) \\
\hline
\end{tabular}

a IPCC (2006a)

b Pellets are considered equivalent to the "other primary solid biomass" fuel category at the IPCC, 2006a. The emission factor of pellet combustion is modified to zero, as this study assumes "net zero $\mathrm{CO}_{2}$ emission". Moreover, $\mathrm{CH}_{4}$ and $\mathrm{N}_{2} \mathrm{O}$ emissions from pellet combustion are only considered in the scenario model for sensitivity analysis (see Table 9).

Table S7.

The ecoinvent dataset used in this study.

\begin{tabular}{|c|c|c|c|}
\hline No. & Flow & Dataset name & Life cycle stage \\
\hline 1 & Diesel & Diesel $\{$ RoW $\} \mid$ market for $\mid$ APOS, S & $\begin{array}{l}\text { Sorghum cultivation, pellet } \\
\text { processing }\end{array}$ \\
\hline 2 & Compost & Compost $\{$ RoW $\} \mid$ treatment of biowaste, industrial composting |APOS, S & Sorghum cultivation \\
\hline 3 & Sorghum seed & Wheat seed, for sowing $\{$ GLO $\} \mid$ market for $\mid$ APOS, $S$ & Sorghum cultivation \\
\hline 4 & $\mathrm{~N}$ fertiliser & Urea, as $\mathrm{N}\{\mathrm{GLO}\} \mid$ market for $\mid$ APOS, $\mathrm{S}$ & Sorghum cultivation \\
\hline 5 & P fertiliser & Phosphate fertiliser, as P2O5 \{GLO $\} \mid$ market for $\mid$ APOS, S & Sorghum cultivation \\
\hline 6 & $\mathrm{~K}$ fertiliser & Potassium fertiliser, as $\mathrm{K} 2 \mathrm{O}\{\mathrm{GLO}\} \mid$ market for $\mid$ APOS, S & Sorghum cultivation \\
\hline 7 & Furadan $^{\mathrm{a}}$ & [thio]carbamate-compound $\{\mathrm{GLO}\} \mid$ market for $\mid$ APOS, $\mathrm{S}$ & Sorghum cultivation \\
\hline 8 & Decis $^{\mathrm{b}}$ & Pyrethroid-compound $\{$ GLO $\} \mid$ market for $\mid$ APOS, $\mathrm{S}$ & Sorghum cultivation \\
\hline 9 & Lubricating oil and grease ${ }^{\mathrm{c}}$ & Lubricating oil $\{$ RoW $\} \mid$ market for lubricating oil $\mid$ APOS, S & Pellet processing \\
\hline 10 & Pellet factory & Wood pellet factory $\{$ GLO $\} \mid$ market for $\mid$ APOS, S & Pellet processing \\
\hline 11 & Electricity mix Indonesia & Electricity, medium voltage $\{$ ID $\} \mid$ market for $\mid$ APOS, S & Pellet processing \\
\hline 12 & Oil waste treatment & Waste mineral oil $\{$ RoW $\} \mid$ market for waste mineral oil $\mid$ APOS, S & Pellet processing \\
\hline 13 & Land transport & $\begin{array}{l}\text { Transport, freight, lorry } 16-32 \text { metric ton, euro } 3\{\text { RoW }\} \mid \text { market for transport, freight, } \\
\text { lorry 16-32 metric ton, EURO3 | APOS, S }\end{array}$ & Transport I \& II \\
\hline 14 & Sea transport & Transport, freight, sea, transoceanic ship $\{$ GLO $\} \mid$ market for $\mid$ APOS, S & Transport III \\
\hline 15 & Brown coal & Lignite $\{$ RoW $\} \mid$ market for $\mid$ APOS, $S^{d}$ & Electricity generation \\
\hline 16 & Lime & Lime $\{$ RoW $\} \mid$ market for lime $\mid$ APOS, $S$ & Electricity generation \\
\hline 17 & Limestone & Limestone, crushed, washed $\{$ RoW $\} \mid$ market for limestone, crushed, washed |APOS, S & Electricity generation \\
\hline 18 & Power plant & Hard coal power plant $\{\mathrm{GLO}\} \mid$ market for $\mid$ APOS, $S$ & Electricity generation \\
\hline 19 & Waste treatment for coal ash & Lignite ash $\{$ RoW $\} \mid$ market for lignite ash $\mid$ APOS, $S$ & Electricity generation \\
\hline 20 & $\begin{array}{l}\text { Waste treatment for wood } \\
\text { ash }\end{array}$ & Wood ash mixture, pure $\{$ RoW $\} \mid$ market for wood ash mixture, pure $\mid$ APOS, $S$ & Electricity generation \\
\hline
\end{tabular}

${ }^{a}$ Furadan is considered equivalent to carbamate (NCBI, 2004)

${ }^{\mathrm{b}}$ Decis is considered equivalent to pyrethroid (NCBI, 2014)

${ }^{c}$ Lubricating oil and grease are considered equivalent (Elduque et al., 2015)

${ }^{\mathrm{d}}$ This dataset does not seem to consider coal-mine fire. 
Table S8.

Chemical analysis of pellets.

\begin{tabular}{|c|c|c|c|c|}
\hline Parameter & Unit & Aa received & Dry basis & Test Method \\
\hline Total moisture & wt. $\%$ & 3.64 & - & ASTM D 2961 - 17 \\
\hline Ash content & wt.\% & 7.28 & 7.56 & ASTM D $3174-12$ \\
\hline Volatile matter & wt. $\%$ & 70.90 & 73.58 & ASTM D $3175-18$ \\
\hline Fixed carbon & wt. $\%$ & 18.18 & 18.86 & ASTM D $3172-13$ \\
\hline Total sulfur & wt. $\%$ & 0.09 & 0.09 & ASTM D $4239-18$ \\
\hline Gross caloric value & $\mathrm{Kcal} / \mathrm{Kg}$ & 4156 & 4313 & ASTM D $5865-13$ \\
\hline \multicolumn{5}{|l|}{ Ultimate analysis } \\
\hline Carbon & wt. $\%$ & 45.61 & 47.33 & ASTM D $5373-16$ \\
\hline Hydrogen & wt. $\%$ & 5.18 & 5.37 & ASTM D $5373-16$ \\
\hline Nitrogen & wt. $\%$ & 0.36 & 0.38 & ASTM D $5373-16$ \\
\hline Oxygen & wt.\% & 37.84 & 39.27 & ASTM D $3176-15$ \\
\hline Parameter & \multicolumn{4}{|c|}{ Test results } \\
\hline Aluminum (AI) & $\mathrm{mg} / \mathrm{kg}$ & \multicolumn{2}{|c|}{1.02} & ISO $16967: 2015$ \\
\hline Calcium (Ca) & $\mathrm{mg} / \mathrm{kg}$ & \multicolumn{2}{|c|}{8.59} & ISO $16967: 2015$ \\
\hline Silicon (Si) & $\mathrm{mg} / \mathrm{kg}$ & \multicolumn{2}{|c|}{24.42} & ISO $16967: 2015$ \\
\hline Zinc (Zn) & ppm & \multicolumn{2}{|c|}{609.56} & ICP \\
\hline Lead $(\mathrm{Pb})$ & ppm & \multicolumn{2}{|c|}{63.25} & ICP \\
\hline Cadmium (Cd) & ppm & \multicolumn{2}{|c|}{2.99} & ICP \\
\hline Nickel (Ni) & ppm & \multicolumn{2}{|c|}{54.03} & ICP \\
\hline Chromium (Cr) & ppm & \multicolumn{2}{|c|}{84.41} & ICP \\
\hline Copper $(\mathrm{Cu})$ & ppm & \multicolumn{2}{|c|}{242.78} & ICP \\
\hline Mercury (Hg) & ppm & \multicolumn{2}{|c|}{13.65} & AAS \\
\hline Arsenic (As) & ppm & \multicolumn{2}{|c|}{0.60} & AAS \\
\hline Chlorine $\left(\mathrm{Cl}_{2}\right)$ & wt.\% & \multicolumn{2}{|c|}{0.04} & ASTM D $7359-18$ \\
\hline Bulk Density & $\mathrm{Kg} / \mathrm{m}^{3}$ & \multicolumn{2}{|c|}{626} & ASTM D 1895 \\
\hline
\end{tabular}

Table S9.

Domestic coal consumption 2013-2018*.

\begin{tabular}{ll}
\hline Year & Steam coal (ton) \\
\hline 2013 & $39,601,034.00$ \\
2014 & $44,604,980.72$ \\
2015 & $48,995,169.00$ \\
2016 & $50,556,446.00$ \\
2017 & $54,711,846.87$ \\
2018 & $60,481,244.55$ \\
\hline
\end{tabular}

* Source: PLN (2019) 
Table S10.

Energy and material requirements for pellet processing.

\begin{tabular}{|c|c|c|c|c|}
\hline No. & Name & $\begin{array}{c}\text { Power required /equipment } \\
\text { (kW/unit) } \\
\text { (1) }\end{array}$ & $\begin{array}{c}\text { Number of equipment } \\
\text { (unit) } \\
\text { (2) }\end{array}$ & $\begin{array}{l}\text { Total power required } \\
(\mathbf{k W}) \\
(\mathbf{1}) *(2)\end{array}$ \\
\hline \multicolumn{5}{|c|}{ Crushing Section } \\
\hline 1 & Chain feeding conveyor & 3 & 1 & 3 \\
\hline 2 & Chipper & 150 & 1 & 150 \\
\hline 3 & Belt conveyor & 7.5 & 1 & 7.5 \\
\hline \multicolumn{5}{|c|}{ Pre-grinding section } \\
\hline 1 & Belt conveyor & 4 & 3 & 12 \\
\hline 2 & Hammer factory & 132 & 3 & 396 \\
\hline 3 & Fan blower & 37 & 3 & 111 \\
\hline 4 & Airlock & 4 & 3 & 12 \\
\hline 5 & Belt conveyor & 7.5 & 1 & 7.5 \\
\hline 6 & Bucket elevator & 7.5 & 1 & 7.5 \\
\hline 7 & Screw conveyor & 7.5 & 1 & 7.5 \\
\hline 8 & Hydraulic bin & 11 & 1 & 11 \\
\hline 9 & Screw conveyor & 7.5 & 1 & 7.5 \\
\hline \multicolumn{5}{|c|}{ Drying section } \\
\hline 1 & Belt conveyor & 4 & 1 & 4 \\
\hline 2 & Bucket elevator & 11 & 1 & 11 \\
\hline 3 & Buffer silo & 11 & 1 & 11 \\
\hline 4 & Belt conveyor & 2.2 & 2 & 4.4 \\
\hline 5 & Airlock & 5.5 & 2 & 11 \\
\hline 6 & Rum rotary dryer & 37 & 2 & 74 \\
\hline 7 & Screw conveyor & 7.5 & 4 & 30 \\
\hline 8 & Fan blower & 55 & 2 & 110 \\
\hline 9 & Airlock & 4 & 4 & 16 \\
\hline 10 & Belt conveyor & 3 & 2 & 6 \\
\hline 11 & Bucket elevator & 7.5 & 2 & 15 \\
\hline 12 & Screw conveyor & 7.5 & 1 & 7.5 \\
\hline 13 & Hydraulic bin & 22 & 1 & 22 \\
\hline 14 & Screw conveyor & 5.5 & 2 & 11 \\
\hline \multicolumn{5}{|c|}{ Fine-grinding section } \\
\hline 1 & Belt conveyor & 3 & 2 & 6 \\
\hline 2 & Hummer factory & 132 & 2 & 264 \\
\hline 3 & Fan blower & 37 & 2 & 74 \\
\hline 4 & Airlock & 4 & 2 & 8 \\
\hline 5 & Belt conveyor & 5.5 & 2 & 11 \\
\hline 6 & Bucket elevator & 7.5 & 1 & 7.5 \\
\hline 7 & Screw conveyor & 7.5 & 1 & 7.5 \\
\hline 8 & Hydraulic bin & 22 & 1 & 22 \\
\hline 9 & Screw conveyor & 5.5 & 2 & 11 \\
\hline \multicolumn{5}{|c|}{ Pellet processing section } \\
\hline 1 & Belt conveyor & 3 & 2 & 6 \\
\hline 2 & Bucket elevator & 7.5 & 2 & 15 \\
\hline 3 & Buffer silo & 5.5 & 1 & 5.5 \\
\hline 4 & Screw feeder & 4 & 4 & 16 \\
\hline 5 & Pellet machine & 227 & 4 & 908 \\
\hline 6 & Belt conveyor & 3 & 1 & 3 \\
\hline \multicolumn{5}{|c|}{ Cooling section } \\
\hline 1 & Bucket elevator & 7.5 & 1 & 7.5 \\
\hline 2 & Airlock & 4 & 1 & 4 \\
\hline 3 & Fan blower & 55 & 1 & 55 \\
\hline 4 & Simple screener & 0.5 & 1 & 0.5 \\
\hline 5 & Bucket elevator & 2.2 & 1 & 2.2 \\
\hline \multicolumn{5}{|c|}{ Packing section } \\
\hline 1 & Bucket elevator & 7.5 & 1 & 7.5 \\
\hline 2 & Jumbo bag packing & 0.55 & 1 & 0.55 \\
\hline \multicolumn{5}{|c|}{ Workshop dust removing section } \\
\hline 1 & Bug dust removing system & 37 & 1 & 37 \\
\hline \\
\hline \multicolumn{5}{|c|}{ Energy consumption: $1,784 \mathrm{kWh}^{\mathrm{a}}$} \\
\hline \multicolumn{5}{|c|}{ Required transformer: $3,185 \mathrm{kVA}$} \\
\hline \multicolumn{5}{|c|}{ Material (reference flow $=$ daily pellet processing ${ }^{\mathbf{b}}$ ) } \\
\hline & Flow & Amount & & Unit \\
\hline & Lubricating oil & 1 & & $\mathrm{~L}$ \\
\hline & Diesel & 65 & & $\mathrm{~L}$ \\
\hline & Grease & 100 & & $\mathrm{~L}$ \\
\hline
\end{tabular}

Please cite this article as: Wiloso E.I., Setiawan A.A.R., Prasetia H., Muryanto, Wiloso A.R., Subyakto, Sudiana I.M., Lestari R., Nugroho S., Hermawan D., Fang K., Heijungs R. Production of sorghum pellets for electricity generation in Indonesia: A life cycle assessment. Biofuel Research Journal 27 (2020) 1178 1194. DOI: $10.18331 /$ BRJ2020.7.3.2 
Table S11.

Inventory of $1 \mathrm{kWh}$ electricity generation*.

\begin{tabular}{lc}
\hline Material & Amount $(\mathbf{k g} / \mathbf{k W h}$ net) \\
\hline Coal -input (as-received) & 0.436 \\
Lime for FGC waste treatment (input) & 0.006 \\
Limestone (input) & 0.078 \\
FGC waste ${ }^{1}$-dry total & 0.085 \\
Ash -moisture free total & 0.031 \\
\hline * Source: Widiyanto et al. (2003) & \\
${ }^{1}$ In this study, FGC waste is considered equivalent to coal-ash waste (Spath \\
et al., 1999).
\end{tabular}

Table S12.

Coal power plant distribution in Indonesia*.

\begin{tabular}{|c|c|c|c|c|c|c|}
\hline No & Power plant name & Owner & Location & Commercial Operating Date & Capacity (MW) & Status \\
\hline 1 & Nagan Raya & PLN & Aceh & Existing & 220 & In operation \\
\hline 2 & Pangkalan Susu & PLN & North Sumatera & Existing & 440 & In operation \\
\hline 3 & Labuhan Angin & PLN & North Sumatera & Existing & 230 & In operation \\
\hline 4 & Bukit Carok & PLN & Riau & Existing & 14 & In operation \\
\hline 5 & Air Raja & PLN & Riau & Existing & 30 & In operation \\
\hline 6 & Suge & PLN & Bangka Belitung & Existing & 16.5 & In operation \\
\hline 7 & Babel 3 & PLN & Bangka Belitung & Existing & 60 & In operation \\
\hline 8 & Ombilin & PLN & West Sumatera & Existing & 190 & In operation \\
\hline 9 & Teluk Sirih & PLN & West Sumatera & Existing & 224 & In operation \\
\hline 10 & Bukit Asam & PLN & South Sumatera & Existing & 260 & In operation \\
\hline 11 & Tarahan & PLN & Lampung & Existing & 300 & In operation \\
\hline 12 & Suralaya 1- 7 & IPP & Banten & Existing & 3,400 & In operation \\
\hline 13 & Suralaya 8 & PLN & Banten & Existing & 625 & In operation \\
\hline 14 & Labuan $1-3$ & PLN & Banten & Existing & 600 & In operation \\
\hline 15 & Lontar $1-3$ & PLN & Banten & Existing & 945 & In operation \\
\hline 16 & Indramayu $1-3$ & PLN & West Java & Existing & 990 & In operation \\
\hline 17 & Cirebon & IPP & West Java & Existing & 660 & In operation \\
\hline 18 & Pelabuhan Ratu $1-3$ & PLN & West Java & Existing & 1,050 & In operation \\
\hline 19 & Cilacap 1-2 & IPP & Central Java & Existing & 600 & In operation \\
\hline 20 & Tanjung Jati B $1-2$ & PLN & Central Java & Existing & 1,320 & In operation \\
\hline 21 & Tanjung Jati B $3-4$ & PLN & Central Java & Existing & 1,320 & In operation \\
\hline 22 & Rembang & PLN & Central Java & Existing & 630 & In operation \\
\hline 23 & Paiton & PJB & East Java & Existing & 800 & In operation \\
\hline 24 & Paiton PEC & IPP & East Java & Existing & 1,230 & In operation \\
\hline 25 & Paiton JP & IPP & East Java & Existing & 1,220 & In operation \\
\hline 26 & Paiton 3 & PLN & East Java & Existing & 815 & In operation \\
\hline 27 & Paiton 9 & PLN & East Java & Existing & 660 & In operation \\
\hline 28 & Pacitan $1-2$ & PLN & East Java & Existing & 630 & In operation \\
\hline 29 & Tanjung Awar - awar 1 & PLN & East Java & Existing & 350 & In operation \\
\hline 30 & Celukan Bawang & IPP & Bali & Existing & 380 & In operation \\
\hline 31 & Sistem Barito & PLN & South Kalimantan & Existing & 260 & In operation \\
\hline 32 & Sistem Barito & IPP & South Kalimantan & Existing & 86 & In operation \\
\hline 33 & Amurang & PLN & North Sulawesi & Existing & 50 & In operation \\
\hline 34 & Sistem Palu-Parigi & IPP & Central Sulawesi & Existing & 27 & In operation \\
\hline 35 & Molotabu & IPP & Gorontalo & Existing & 20 & In operation \\
\hline 36 & Barru $1-2$ & PLN & South Sulawesi & Existing & 100 & In operation \\
\hline 37 & Jeneponto $1-2$ & IPP & South Sulawesi & Existing & 200 & In operation \\
\hline 38 & Kendari & PLN & Southeast Sulawesi & Existing & 20 & In operation \\
\hline 39 & Bau-bau & PLN & Southeast Sulawesi & Existing & 14 & In operation \\
\hline 40 & TB Karimun 2 (FTP1) & PLN & Riau & 2016 & 7 & Under construction \\
\hline 41 & Belitung Baru 2 (FTP1) & PLN & Bangka Belitung & 2016 & 16.5 & Under construction \\
\hline 42 & Keban Agung & IPP & South Sumatera & 2016 & 225 & Under construction \\
\hline 43 & Sumsel 5 & IPP & South Sumatera & 2016 & 300 & Under construction \\
\hline 44 & Tarahan 4 (FTP1) & PLN & Lampung & 2016 & 100 & Under construction \\
\hline 45 & Adipala & PLN & Central Java & 2016 & 660 & Under construction \\
\hline 46 & Cilacap exp & IPP & Central Java & 2016 & 614 & Under construction \\
\hline
\end{tabular}

Please cite this article as: Wiloso E.I., Setiawan A.A.R., Prasetia H., Muryanto, Wiloso A.R., Subyakto, Sudiana I.M., Lestari R., Nugroho S., Hermawan D., Fang K., Heijungs R. Production of sorghum pellets for electricity generation in Indonesia: A life cycle assessment. Biofuel Research Journal 27 (2020) 1178 1194. DOI: $10.18331 / \mathrm{BRJ} 2020.7 .3 .2$ 
Tahle S12.

\begin{tabular}{|c|c|c|c|c|c|c|}
\hline No & Power plant name & Owner & Location & Commercial Operating Date & Capacity (MW) & Status \\
\hline 47 & Tanjung Awar-awar & PLN & East Java & 2016 & 350 & Under construction \\
\hline 48 & Sintang & PLN & West Kalimantan & $2016 / 17$ & 21 & Under construction \\
\hline 49 & Ketapang & IPP & West Kalimantan & $2016 / 17$ & 12 & Under construction \\
\hline 50 & Ketapang & PLN & West Kalimantan & 2016 & 10 & Under construction \\
\hline 51 & Pulau Pisau & PLN & Central Kalimantan & 2016 & 120 & Under construction \\
\hline 52 & Teluk Balikpapan (FTP1) & PLN & East Kalimantan & 2016 & 220 & Under construction \\
\hline 53 & Tawaeli (exp) & IPP & Central Sulawesi & 2016 & 30 & Under construction \\
\hline 54 & Maluku Utara / Tidore (FTP1) & PLN & North Maluku & 2016 & 14 & Under construction \\
\hline 55 & Jayapura (FTP1) & PLN & Papua & 2016 & 20 & Under construction \\
\hline 56 & Lombok (FTP1) & PLN & NTB & 2016 & 50 & Under construction \\
\hline 57 & Bima (FTP1) & PLN & NTB & 2016 & 20 & Under construction \\
\hline 58 & Ende & PLN & NTT & 2016 & 7 & Under construction \\
\hline 59 & Kupang & IPP & NTT & 2016 & 30 & Under construction \\
\hline 60 & Kotabaru & PLN & South Kalimantan & 2017 & 14 & Under construction \\
\hline 61 & Kuala Pambuang & PLN & South Kalimantan & 2017 & 6 & Under construction \\
\hline 62 & Tanjung Redep & PLN & East Kalimantan & 2017 & 14 & Under construction \\
\hline 63 & Tanah Grogot & IPP & East Kalimantan & 2017 & 14 & Under construction \\
\hline 64 & Malinau & PLN & North Kalimantan & 2017 & 6 & Under construction \\
\hline 65 & Parit Bary (FTP1) & PLN & West Kalimantan & $2017 / 18$ & 100 & Under construction \\
\hline 66 & Kaltim (MT) & IPP & East Kalimantan & $2017 / 18$ & 52 & Under construction \\
\hline 67 & Amurang & IPP & North Sulawesi & $2017 / 18$ & 50 & Under construction \\
\hline 68 & Tanjung Selow & PLN & North Kalimantan & 2017 & 14 & Under construction \\
\hline 69 & Talaud & PLN & North Sulawesi & 2017 & 6 & Under construction \\
\hline 70 & Ampana & PLN & Central Sulawesi & 2017 & 6 & Under construction \\
\hline 71 & Gorontalo (FTP1) & PLN & Gorontalo & 2017 & 50 & Under construction \\
\hline 72 & Mamuju & IPP & West Sulawesi & 2017 & 50 & Under construction \\
\hline 73 & Sumbawa Barat & PLN & NTB & 2017 & 14 & Under construction \\
\hline 74 & Lombok Timur & IPP & NTB & 2017 & 50 & Under construction \\
\hline 75 & Rote Ndao & PLN & NTT & 2017 & 6 & Under construction \\
\hline 76 & Alor & PLN & NTT & 2017 & 6 & Under construction \\
\hline
\end{tabular}

* Source: Bappenas (2016). It is assumed that all power plants whose status is under construction (with completion targets in 2017) have all been completed in 2017.

Table S13.

Transportation values (from pellet factories to Marapokot port).

Distance and load of land transport from pellet factories to Marapokot port

\begin{tabular}{lccc}
\hline Pellet factory & Distance $(\mathbf{k m})$ & Load (ton pellet) & Transport value (tkm) $^{*}$ \\
\hline $1^{\text {st }}$ & 299 & $1,200,000$ & $358,800,000$ \\
$2^{\text {nd }}$ & 126 & $1,200,000$ & $151,200,000$ \\
$3^{\text {rd }}$ & 49 & $1,200,000$ & $58,800,000$ \\
$4^{\text {th }}$ & 178 & $1,200,000$ & $213,600,000$ \\
Total & $\mathbf{6 5 2}$ & $\mathbf{4 , 8 0 0 , 0 0 0}$ & $\mathbf{7 8 2 . 4 0 0 . 0 0 0}$ \\
\hline${ }^{*}$ tkm=ton $\times \mathrm{km}$ & &
\end{tabular}

Please cite this article as: Wiloso E.I., Setiawan A.A.R., Prasetia H., Muryanto, Wiloso A.R., Subyakto, Sudiana I.M., Lestari R., Nugroho S., Hermawan D., Fang K., Heijungs R. Production of sorghum pellets for electricity generation in Indonesia: A life cycle assessment. Biofuel Research Journal 27 (2020) 1178 1194. DOI: $10.18331 / \mathrm{BRJ} 2020.7 .3 .2$ 
Table S14.

Transportation values (from pellet factories to Marapokot port).

Distance and load of sea transport from Marapokot port to power plants

\begin{tabular}{|c|c|c|c|c|c|c|}
\hline \multicolumn{2}{|c|}{ Port destination } & \multirow{2}{*}{$\begin{array}{l}\text { Coverage area }^{\text {a }} \\
\text { North Sumatera, Riau }\end{array}$} & \multirow{2}{*}{$\frac{\text { Electricity }^{\mathbf{b}}(\mathbf{G W h})}{4.87 \mathrm{E} 3}$} & \multirow{2}{*}{$\begin{array}{c}\text { Distance (km) } \\
2.44 \mathrm{E} 3\end{array}$} & \multirow{2}{*}{$\begin{array}{c}\text { Load (ton pellet) } \\
1.41 \mathrm{E} 5\end{array}$} & \multirow{2}{*}{$\begin{array}{c}\text { Transport (tkm) } \\
3.44 \mathrm{E} 8\end{array}$} \\
\hline $\mathrm{A}$ & Riau Islands & & & & & \\
\hline $\mathrm{B}$ & Bangka Belitung & South Sumatera & $3.77 \mathrm{E} 3$ & $1.87 \mathrm{E} 3$ & $1.09 \mathrm{E} 5$ & 2.03E8 \\
\hline $\mathrm{C}$ & Banten & West Java & $3.56 \mathrm{E} 4$ & $1.68 \mathrm{E} 3$ & $1.03 \mathrm{E} 6$ & $1.72 \mathrm{E} 9$ \\
\hline $\mathrm{E}$ & East Java & Bali & $1.40 \mathrm{E} 4$ & 7.91E2 & 4.03E5 & $3.19 \mathrm{E} 8$ \\
\hline $\mathrm{F}$ & West Kalimantan & - & $2.80 \mathrm{E} 2$ & $1.66 \mathrm{E} 3$ & $8.08 \mathrm{E} 3$ & $1.34 \mathrm{E} 7$ \\
\hline $\mathrm{G}$ & South Kalimantan & - & $2.12 \mathrm{E} 3$ & $1.00 \mathrm{E} 3$ & $6.11 \mathrm{E} 4$ & $6.12 \mathrm{E} 7$ \\
\hline $\mathrm{H}$ & North Kalimantan & East Kalimantan & $3.91 \mathrm{E} 2$ & $1.71 \mathrm{E} 3$ & $1.13 \mathrm{E} 4$ & $1.93 \mathrm{E} 7$ \\
\hline J & East Nusa Tenggara & West Nusa Tenggara & $4.48 \mathrm{E} 2$ & $0^{\mathrm{c}}$ & $1.29 \mathrm{E} 4$ & 0 \\
\hline $\mathrm{K}$ & Southeast Sulawesi & - & $1.51 \mathrm{E} 2$ & $5.04 \mathrm{E} 2$ & 4.37E3 & $2.20 \mathrm{E} 6$ \\
\hline $\mathrm{L}$ & North Sulawesi & - & $2.30 \mathrm{E} 2$ & $1.25 \mathrm{E} 3$ & $6.64 \mathrm{E} 3$ & $8.28 \mathrm{E} 6$ \\
\hline $\mathrm{M}$ & Maluku & & $7.48 \mathrm{E} 1$ & $1.05 \mathrm{E} 3$ & $2.16 \mathrm{E} 3$ & $2.28 \mathrm{E} 6$ \\
\hline $\mathrm{N}$ & Papua & West Papua & $1.48 \mathrm{E} 2$ & $2.86 \mathrm{E} 3$ & $4.26 \mathrm{E} 3$ & $1.22 \mathrm{E} 7$ \\
\hline \multicolumn{3}{|c|}{ Total } & $1.06 \mathrm{E} 5$ & $1.85 \mathrm{E} 4$ & $3.05 \mathrm{E} 6$ & 4.35E9 \\
\hline
\end{tabular}

\footnotetext{
${ }^{\mathrm{a}}$ Including the port area that receives pellet.

${ }^{\mathrm{b}}$ Based on the 2017 national electricity report data (MEMR, 2018b), some values per region are the result of calculations by the author because some data cannot be directly divided into regions in this study, but the total value is the same $(105,651.39 \mathrm{GWh})$.
}

${ }^{\mathrm{c}}$ Port of pellet provider. The distance value is zero, as the port is a supplier of the pellet.

Table S15.

Indonesian coal electricity production in $2017^{*}$.

\begin{tabular}{lll}
\hline No & Region & Coal electricity production (GWh) \\
\hline 1 & Riau Islands & 50.26 \\
2 & Bangka Belitung & 287.11 \\
3 & West Kalimantan & 158.96 \\
4 & South Kalimantan & $2,115.55$ \\
5 & East Kalimantan & 391.40 \\
6 & North Sulawesi & 229.91 \\
7 & South Sulawesi & 423.51 \\
8 & South East Sulawesi & 151.43 \\
9 & Maluku & 74.82 \\
10 & Papua & 17.29 \\
11 & West Papua & 9.49 \\
12 & West Nusa Tenggara & 159.86 \\
13 & East Nusa Tenggara & 123.31 \\
14 & Kit Sumbagut & $3,612.36$ \\
15 & Kit Sumbagsel & $3,483.99$ \\
\hline Outside Java & $\mathbf{1 1 , 2 8 9 . 2 5}$ \\
\hline 16 & PT. Indonesia Power & $23,894.44$ \\
17 & PT. PJB & $9,809.39$ \\
18 & Pembangkitan Tanjung Jati B & $19,352.86$ \\
19 & Kit Jawa Bagian Barat & $12,466.92$ \\
20 & Kit Jawa Bagian Tengah & $17,563.24$ \\
21 & Kit Jawa Bagian Timur dan Bali & $11,275.29$ \\
\hline Java & & $\mathbf{9 4 , 3 6 2 . 1 4}$ \\
\hline Outside Java + Java (Indonesia) & $\mathbf{1 0 5 , 6 5 1 . 3 9}$ \\
\hline Source: PLN (2018) & \\
\hline
\end{tabular}

Table S16.

Field emission.

\begin{tabular}{|c|c|c|c|}
\hline \multicolumn{4}{|c|}{ Nitrous oxide emissions from sorghum cultivation stages } \\
\hline \multirow{2}{*}{ Life cycle stages } & \multicolumn{2}{|c|}{ Input flow (kg/ha.year) } & \multirow{2}{*}{$\begin{array}{c}\mathrm{N}_{2} \mathrm{O} \\
(\mathrm{kg} / \mathrm{ha} \text { a.year })^{\mathrm{c}}\end{array}$} \\
\hline & Synthetic Fertilizer ${ }^{a}$ & Compost $^{b}$ & \\
\hline Land processing & - & 5,000 & 1.34 \\
\hline Planting & 200 & - & 1.57 \\
\hline Fertilizing & 150 & - & 1.18 \\
\hline Maintenance & - & - & - \\
\hline Harvesting & - & - & - \\
\hline Total emission & & & 4.09 \\
\hline \multicolumn{4}{|c|}{${ }^{a}$ Synthetic fertilizer: $50 \%$ N-content (data from field-trial in Gresik, East Java) } \\
\hline \multicolumn{4}{|c|}{ b Compost: $1.71 \%$ N-content (based on a study conducted by Kim et al., 2014) } \\
\hline \multicolumn{4}{|c|}{$\begin{array}{l}{ }^{c} \text { IPCC (2006b). The current study only calculates direct } \mathrm{N}_{2} \mathrm{O} \text { emissions and only } \\
\text { those that come from fertilizer applications. }\end{array}$} \\
\hline
\end{tabular}

Parameter values for calculation of $\mathrm{N}_{2} \mathrm{O}$ field (direct) emission (area of 1 ha)

\begin{tabular}{|c|c|c|}
\hline Parameter & Value & Unit \\
\hline$\overline{\mathrm{F}_{\mathrm{SN}}{ }^{\mathrm{a}}}$ & 175 & $\mathrm{~kg} \mathrm{~N} \mathrm{yr}^{-1}$ \\
\hline $\mathrm{F}_{\mathrm{ON}}{ }^{\mathrm{b}}$ & 85.5 & $\mathrm{~kg} \mathrm{~N} \mathrm{yr}^{-1}$ \\
\hline $\mathrm{F}_{\mathrm{CR}}^{\mathrm{c}}$ & 0 & $\mathrm{~kg} \mathrm{~N} \mathrm{yr}^{-1}$ \\
\hline $\mathrm{F}_{\mathrm{SOM}}{ }^{\mathrm{c}}$ & 0 & $\mathrm{~kg} \mathrm{~N} \mathrm{yr}^{-1}$ \\
\hline $\mathrm{N}_{2} \mathrm{O}-\mathrm{N}_{\mathrm{N} \text { inputs }}$ & 260.5 & $\mathrm{~kg} \mathrm{~N} \mathrm{yr}^{-1}$ \\
\hline$\overline{\mathrm{EF}_{1}}$ & 0.01 & $\mathrm{~kg} \mathrm{~N}_{2} \mathrm{O}-\mathrm{N}(\mathrm{kg} \mathrm{N})^{-1}$ \\
\hline $\mathrm{N}_{2} \mathrm{O}_{\text {Direct }}-\mathrm{N}^{\mathrm{d}}$ & 2.61 & $\mathrm{~kg} \mathrm{~N}_{2} \mathrm{O}-\mathrm{N} \mathrm{yr}^{-1}$ \\
\hline $\mathrm{N}_{2} \mathrm{O}_{\text {Direct }}$ & 4.09 & $\mathrm{~kg} \mathrm{~N}_{2} \mathrm{O} \mathrm{yr}^{-1}$ \\
\hline \multirow{2}{*}{\multicolumn{3}{|c|}{$\begin{array}{l}{ }^{\mathrm{a}} \mathrm{F}_{\mathrm{SN}}=\text { annual amount of synthetic fertiliser } \mathrm{N} \text { applied to soils; } \mathrm{F}_{\mathrm{SN}}=(200 \mathrm{~kg}+150 \mathrm{~kg} \\
\text { synthetic fertiliser } \mathrm{N}) \times 50 \%=175 \text {. The } \mathrm{N} \text { content of applied synthetic fertiliser } \mathrm{N} \text { is } 50 \% \\
\text { (from field-trial in Gresik, East Java). } \\
{ }^{\mathrm{b}} \mathrm{F}_{\mathrm{ON}}=\text { annual amount of animal manure, compost, sewage sludge and other organic } \mathrm{N} \\
\text { additions applied to soils; } \mathrm{F}_{\mathrm{ON}}=(5,000 \mathrm{~kg} \text { compost }) \times 1.71 \%=85.5 \text {. The } \mathrm{N} \text { content of } \\
\text { applied compost fertiliser } \mathrm{N} \text { is } 1.71 \% \text { (based on Kim et al., 2014). }\end{array}$}} \\
\hline & & \\
\hline \multicolumn{3}{|c|}{$\begin{array}{l}{ }^{\mathrm{c}} \text { Not considered in this study due to lack of the data. } \mathrm{F}_{\mathrm{CR}}=\text { annual amount of } \mathrm{N} \text { in crop } \\
\text { residues (above-ground and below-ground), including } \mathrm{N} \text {-fixing crops, and from } \\
\text { forage/pasture renewal, returned to soils, } \mathrm{kg} \mathrm{Nyr}{ }^{-1} . \mathrm{F}_{\mathrm{SOM}}=\text { annual amount of } \mathrm{N} \text { in mineral } \\
\text { soils that is mineralised, in association with loss of soil } \mathrm{C} \text { from soil organic matter as a } \\
\text { result of changes to land use or management, } \mathrm{kg} \mathrm{N} \mathrm{yr}^{-1} \text {. }\end{array}$} \\
\hline The convers & & \\
\hline
\end{tabular}

Please cite this article as: Wiloso E.I., Setiawan A.A.R., Prasetia H., Muryanto, Wiloso A.R., Subyakto, Sudiana I.M., Lestari R., Nugroho S., Hermawan D., Fang K., Heijungs R. Production of sorghum pellets for electricity generation in Indonesia: A life cycle assessment. Biofuel Research Journal 27 (2020) 1178 1194. DOI: 10.18331/BRJ2020.7.3.2 
Table S17.

LCI comparison between this study and literature.

\begin{tabular}{|c|c|c|c|c|c|c|}
\hline \multirow[b]{2}{*}{ Life cycle stage } & \multirow[b]{2}{*}{ Input flow } & \multirow[b]{2}{*}{ Unit } & \multicolumn{4}{|c|}{ Crop (amount) } \\
\hline & & & $\begin{array}{l}\text { Sorghum } \\
(48 \mathrm{t} / \mathrm{ha})^{\mathrm{a}}\end{array}$ & $\begin{array}{l}\text { Miscanthus } \\
(20 \text { t/ha })^{\mathbf{b}}\end{array}$ & $\begin{array}{c}\text { Misacanthis } \\
(11.5 \mathrm{t} / \mathrm{ha})^{\mathrm{c}}\end{array}$ & $\begin{array}{l}\text { Switchgrass } \\
(13.9 \mathrm{t} / \mathrm{ha})^{\mathrm{d}}\end{array}$ \\
\hline \multirow{3}{*}{ Land processing } & Diesel & $\mathrm{L}$ & 134 & - & - & - \\
\hline & Compost & ton & 5 & - & - & - \\
\hline & Manpower & $\mathrm{mwd}^{*}$ & 80 & - & - & - \\
\hline \multirow{8}{*}{ Planting } & Sorghum seed & $\mathrm{kg}$ & 30 & - & - & - \\
\hline & Nitrogen fertilizer & $\mathrm{kg}$ & 200 & 100 & 60 & 66.30 \\
\hline & Phosphate fertilizer & $\mathrm{kg}$ & 150 & 50 & 9 & 6.81 \\
\hline & Potassium fertilizer & $\mathrm{kg}$ & 15 & 200 & 58.75 & - \\
\hline & Furadan (pesticide) & $\mathrm{kg}$ & 5 & - & - & 1.39 \\
\hline & Decis (pesticide) & $\mathrm{L}$ & 2 & - & - & - \\
\hline & Water, from well & $\mathrm{L}$ & 20,000 & - & - & - \\
\hline & Man power & $\mathrm{mwd}^{*}$ & 60 & - & - & - \\
\hline \multirow{3}{*}{ Fertilizing } & Nitrogen fertilizer & $\mathrm{kg}$ & 150 & - & - & - \\
\hline & Phosphate fertilizer & $\mathrm{kg}$ & 150 & - & - & - \\
\hline & Potassium fertilizer & $\mathrm{kg}$ & 150 & - & - & - \\
\hline \multirow{2}{*}{ Maintenance } & Manpower & $\mathrm{mwd}^{*}$ & 190 & - & - & - \\
\hline & Diesel & $\mathrm{L}$ & 100 & - & - & - \\
\hline Harvesting & Manpower & $\mathrm{mwd}^{*}$ & 140 & - & - & - \\
\hline \multirow{6}{*}{ Pelleting } & Biomass & ton & 48 & 20 & 11.5 & 13.21 \\
\hline & Pellet factory ${ }^{1)}$ & Piece $^{2)}$ & $5.0 \mathrm{E}-5$ & - & - & - \\
\hline & Electricity & $\mathrm{kWh}$ & 7,136 & 1,802 & 668 & 2,025 \\
\hline & Diesel & $\mathrm{L}$ & 37.152 & - & - & - \\
\hline & Lubricating oil & $\mathrm{L}$ & 0.576 & - & - & - \\
\hline & Grease & $\mathrm{L}$ & 2.4 & - & - & - \\
\hline \multicolumn{7}{|c|}{$\begin{array}{l}\text { *mwd = man work-day is defined as work done by one person in one day for eight hours (Wahyuni, 2014). } \\
\text { 1) added by referring to the ecoinvent dataset because of limited primary data. } \\
\text { 2) unit for infrastructure (pellet factory). One-piece }=\text { total pellet processing during the life span of infrastructure }(24,000 \text { ton/year } * 40 \text { years }=960,000 \text { ton). } 48 \text {-ton pellet } \\
\text { processing requires only } 48 / 960,000 \text { piece of infrastructure, which is } 5.05 \mathrm{E}-5 \text { piece. }\end{array}$} \\
\hline \multicolumn{7}{|c|}{ a This study } \\
\hline \multicolumn{7}{|c|}{ ' ${ }^{\mathrm{L}}$ Lewdowski (1995) } \\
\hline \multicolumn{7}{|c|}{$\begin{array}{l}{ }^{\mathrm{c}} \text { Murphy et al. (2013) } \\
{ }^{\mathrm{d}} \text { Bergman et al. (2015) }\end{array}$} \\
\hline d Bergman et al. (2 & & & & & & \\
\hline
\end{tabular}

Please cite this article as: Wiloso E.I., Setiawan A.A.R., Prasetia H., Muryanto, Wiloso A.R., Subyakto, Sudiana I.M., Lestari R., Nugroho S., Hermawan D., Fang K., Heijungs R. Production of sorghum pellets for electricity generation in Indonesia: A life cycle assessment. Biofuel Research Journal 27 (2020) 11781194. DOI: $10.18331 /$ BRJ2020.7.3.2 


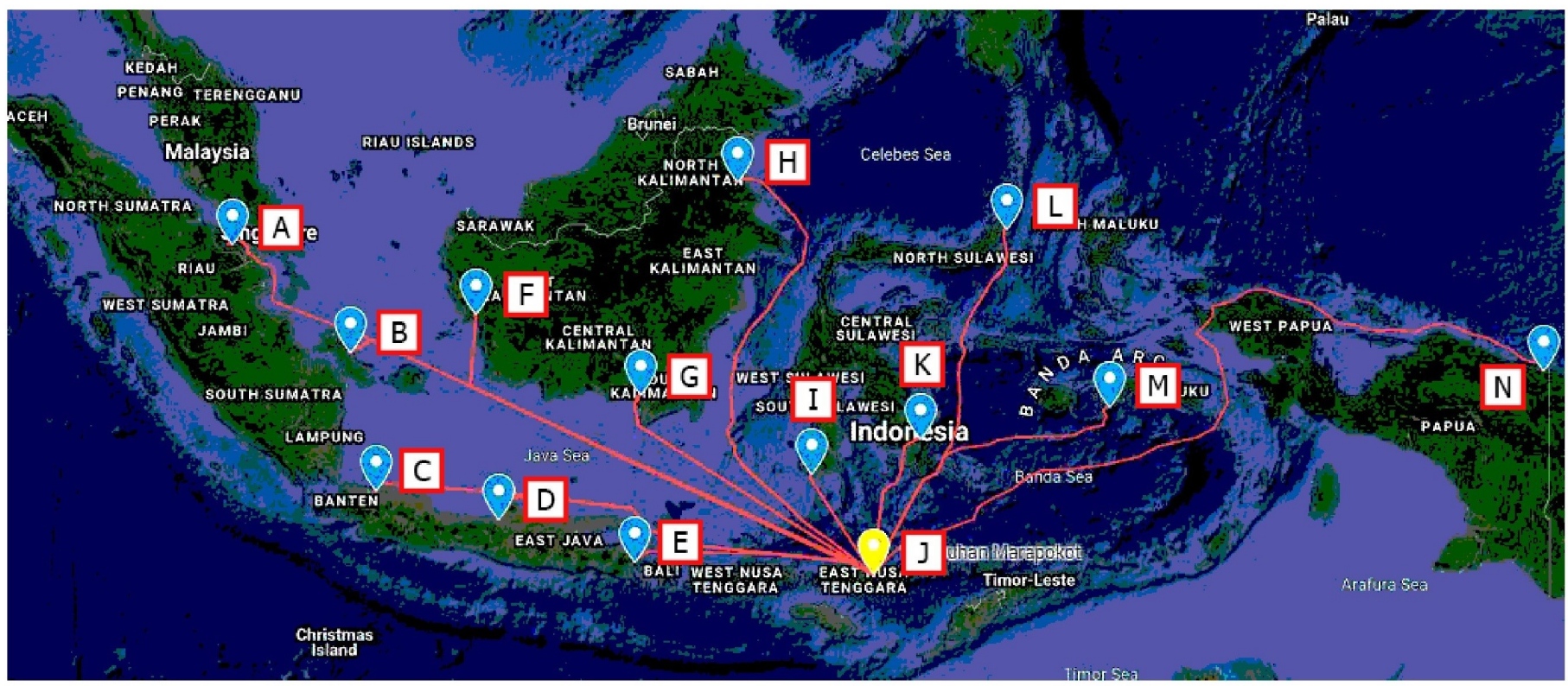

\section{Pellet provider (letter "J")}

\section{Pellet receiver}

Fig. S1. Sea transport map.

\section{References}

[1] Aho, M., Envall, T., Kauppinen, J., 2013. Corrosivity of flue gases during co-firing Chinese biomass with coal at fluidised bed conditions. Fuel Process. Technol. 105, 82-88.

[2] Bappenas, 2016. Laporan Akhir: Kajian Ketercapaian Target DMO Batubara Sebesar 60\% Produksi Nasional pada Tahun 2019.

[3] Bergman, R.D., Reed, D.L., Taylor, A.M., Harper, D.P., Hodges, D.G., 2015. Cradle-to-gate life cycle assessment of switchgrass fuel pellets manufactured in the Southeastern United States1. Wood Fiber Sci. 47(2), 147-159.

[4] BPDASHL Benain Noelmina, 2018. Peta Lahan Kritis Wilayah Kerja BPDAS Benain Noelmina. East Nusa Tenggara.

[5] Elduque, A., Javierre, C., Elduque, D., Fernández, Á., 2015. LCI databases sensitivity analysis of the environmental impact of the injection molding process. Sustainability. 7(4), 3792-3800

[6] Gungor, A., 2013. Simulation of co-firing coal and biomass in circulating fluidized beds. Energy Convers. Manag. 65, 574-579.

[7] IPCC, 2006a. IPCC Guidelines for National Greenhouse Gas Inventories.

[8] IPCC, 2006b. IPCC- $\mathrm{N}_{2} \mathrm{O}$ Emissions from managed Soils and $\mathrm{CO}_{2}$ Emissions From, Agriculture.

[9] Khaerunisa, H., Huda, M., Damayanti, R., Antono, H.T., Komarudin Yaskuri, D., Lutfi, M., Suryati, E., Alimano, M., Nurhadi, H., Sibarani, L., Hayati, I., Mujahidin, S., 2009. Study of $\mathrm{CO}_{2}$ emissions from coal combustion in Indonesia. Bandung.

[10] Kim, S.Y., Pramanik, P., Gutierrez, J., Hwang, H.Y., Kim, P.J., 2014. Comparison of methane emission characteristics in air-dried and composted cattle manure amended paddy soil during rice cultivation. Agric. Ecosyst. Environ. 197, 60-67.

[11] Lewandowski, I., Kicherer, A., Vonier, P., 1995. $\mathrm{CO}_{2}$-balance for the cultivation combustion of Miscanthus. Biomass Bioenergy. 8(2), 81-90.

[12] MEMR, 2018b. Statistik Ketenagalistrikan T.A. 2018. Ministry of Energy and Mineral Resources. Indonesia.

[13] Morrison, B., Golden, J.S., 2017. Life cycle assessment of co-firing coal and wood pellets in the Southeastern United States. J. Clean. Prod. 150, 188-196.
[14] Murphy, F., Devlin, G., McDonnell, K., 2013. Miscanthus production and processing in Ireland: an analysis of energy requirements and environmental impacts. Renew. Sust. Energy Rev. 23, 412-420.

[15] NCBI, 2014. PubChem Database. Deltamethrin, CID $=40585$.

[16] NCBI, 2004. PubChem Database. Carbofuran, CID $=2566$.

[17] PLN, 2018. Statistik PLN 2017. Sekretariat Perusahaan PT PLN (Persero), Jakarta.

[18] PLN, 2019. Buku Statistik PLN 2018. Sekretariat Perusahaan PT PLN (Persero), Jakarta.

[19] PTIP, 2018. Laporan Statistik PT Indonesia Power 2018.

[20] Sathitruangsak, P., Madhiyanon, T., 2017. Effect of Operating Conditions on the Combustion Characteristics of Coal, Rice Husk, and Co-firing of Coal and Rice Husk in a Circulating Fluidized Bed Combustor. Energy Fuels 31, 12741-12755.

[21] Schakel, W., Meerman, H., Talaei, A., Ramírez, A., Faaij, A., 2014. Comparative life cycle assessment of biomass co-firing plants with carbon capture and storage. Appl. Energy. 131, 441-467.

[22] Shafie, S.M., Mahlia, T.M.I., Masjuki, H.H., 2013. Life cycle assessment of rice straw co-firing with coal power generation in Malaysia. Energy 57, 284-294.

[23] Spath, P.L., Mann, M.K., Kerr, D.R., 1999. Life cycle assessment of coal-fired power production. Technical Report: NREL/TP-57025119; TRN: US200307\%\% 179 .

[24] Stromberg, B., 2006. Fuel Handbook. Stockholm (Sweden).

[25] Tabata, T., Torikai, H., Tsurumaki, M., Genchi, Y., Ukegawa, K., 2011. Life cycle assessment for co-firing semi-carbonized fuel manufactured using woody biomass with coal: A case study in the central area of Wakayama, Japan. Renew. Sust. Energy Rev. 15(6), 2772-2778

[26] Wahyuni, N., 2014. Working time allocation and income of cattle farmers at Megang Sakti Subdistrict Musi Rawas Regency. Societa: Jurnal Ilmu-Ilmu Agribisnis.

[27] Widiyanto, A., Kato, S., Maruyama, N., 2003. Environmental impact analysis of indonesian electric generation system (development of a life cycle inventory of indonesian electricity). JSME Int. J. Ser. B. 46(4), 650-659. 
[28] Woytiuk, K., Sanscartier, D., Amichev, B.Y., Campbell, W., Van Rees, K., 2017. Life-cycle assessment of torrefi ed coppice willow co-fi ring with lignite coal in an existing pulverized coal boiler. Biofuel. Bioprod. Bior. 11, 830-846.
[29] Wu, J., Kong, L., Wang, L., Sun, Y., 2016. Life cycle assessment of a co-firing power generation system in China. J. Biobased Mater. Bioenergy 10, 129-136. 